\title{
Front Matter: Volume 6651
}

, "Front Matter: Volume 6651," Proc. SPIE 6651, Photovoltaic Cell and Module Technologies, 665101 (16 October 2007); doi: 10.1117/12.773730

SPIE Event: Solar Energy + Applications, 2007, San Diego, California, United SPIE. States 


\section{PROCEEDINGS OF SPIE}

\section{Photovoltaic Cell and Module Technologies}

Bolko von Roedern

Alan E. Delahoy

Editors

27-28 August 2007

San Diego, California, USA

Sponsored and Published by

SPIE

Volume 6651

Proceedings of SPIE, 0277-786X, v. 6651 
The papers included in this volume were part of the technical conference cited on the cover and title page. Papers were selected and subject to review by the editors and conference program committee. Some conference presentations may not be available for publication. The papers published in these proceedings reflect the work and thoughts of the authors and are published herein as submitted. The publisher is not responsible for the validity of the information or for any outcomes resulting from reliance thereon.

Please use the following format to cite material from this book:

Author(s), "Title of Paper," in Photovoltaic Cell and Module Technologies, edited by

Bolko von Roedern, Alan E. Delahoy, Proceedings of SPIE Vol. 6651 (SPIE, Bellingham, WA, 2007) Article CID Number.

ISSN 0277-786X

ISBN 9780819467997

Published by

SPIE

P.O. Box 10, Bellingham, Washington 98227-0010 USA

Telephone +1 3606763290 (Pacific Time) · Fax +1 3606471445

SPIE.org

Copyright (c) 2007, Society of Photo-Optical Instrumentation Engineers

Copying of material in this book for internal or personal use, or for the internal or personal use of specific clients, beyond the fair use provisions granted by the U.S. Copyright Law is authorized by SPIE subject to payment of copying fees. The Transactional Reporting Service base fee for this volume is $\$ 18.00$ per article (or portion thereof), which should be paid directly to the Copyright Clearance Center (CCC), 222 Rosewood Drive, Danvers, MA 01923. Payment may also be made electronically through CCC Online at copyright.com. Other copying for republication, resale, advertising or promotion, or any form of systematic or multiple reproduction of any material in this book is prohibited except with permission in writing from the publisher. The CCC fee code is $0277-786 \mathrm{X} / 07 / \$ 18.00$.

Printed in the United States of America.

Publication of record for individual papers is online in the SPIE Digital Library.

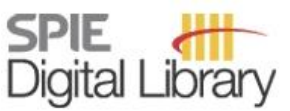

SPIEDigitalLibrary.org

Paper Numbering: Proceedings of SPIE follow an e-First publication model, with papers published first online and then in print and on CD-ROM. Papers are published as they are submitted and meet publication criteria. A unique, consistent, permanent citation identifier (CID) number is assigned to each article at the time of the first publication. Utilization of CIDs allows articles to be fully citable as soon they are published online, and connects the same identifier to all online, print, and electronic versions of the publication. SPIE uses a six-digit CID article numbering system in which:

- The first four digits correspond to the SPIE volume number.

- The last two digits indicate publication order within the volume using a Base 36 numbering system employing both numerals and letters. These two-number sets start with 00, 01, 02, 03, 04, 05, $06,07,08,09,0 \mathrm{~A}, 0 \mathrm{~B} \ldots \mathrm{OZ}$, followed by $10-1 \mathrm{Z}, 20-2 \mathrm{Z}$, etc.

The CID number appears on each page of the manuscript. The complete citation is used on the first page, and an abbreviated version on subsequent pages. Numbers in the index correspond to the last two digits of the six-digit CID number. 


\section{Contents}

$\checkmark$ Conference Committee

vii The solar-hydrogen economy: an analysis (Plenary Paper) [6650-101]

W. D. Reynolds, Eco-Engineers, Inc. (USA)

xxix Solar hydrogen production by tandem cell system composed of metal oxide semiconductor film photoelectrode and dye-sensitized solar cell (Plenary Paper) [6650-102] H. Arakawa, C. Shiraishi, M. Tatemoto, H. Kishida, D. Usui, A. Suma, A. Takamisawa,

T. Yamaguchi, Tokyo Univ. of Science (Japan)

\section{SESSION 1 SOLAR CELL OPERATION}

665102 Detailed balance: lifetimes and efficiencies (Invited Paper) [6651-01]

H. J. Queisser, Max-Planck-Institute for Solids (Germany)

665103 Efficiency enhancement in concentrator solar cells by dielectric micro-concentrators [6651-02]

O. Korech, J. M. Gordon, E. A. Katz, D. Feuermann, Ben-Gurion Univ. of the Negev (Israel);

N. Eisenberg, Jerusalem College of Technology (Israel)

665104 Performance analysis of Culn $1-x G_{x} S_{2}$ (CIGS2) thin film solar cells based on semiconductor properties [6651-03]

N. G. Dhere, A. H. Jahagirdar, S. R. Ghongadi, Florida Solar Energy Ctr. (USA)

665105 Temperature dependence of Si-based thin film solar cells near phase boundary [6651-04] K. Sriprapha, I. A. Yunaz, S. Y. Myong, A. Yamada, M. Konagai, Tokyo Institute of Technology (Japan)

665106 Diffractive and energy selective photonic crystals for thin-film tandem solar cells [6651-05] A. Bielawny, P. T. Miclea, R. B. Wehrspohn, Univ. of Halle-Wittenberg (Germany); A. von Rhein, Univ. of Paderborn (Germany); C. Rockstuhl, M. Lisca, F. L. Lederer, FriedrichSchiller-Univ. Jena (Germany); B. Lange, R. Zentel, Univ. Mainz (Germany); R. Carius, Research Ctr. Jülich GmbH (Germany)

\section{SESSION 2 SOLAR CELL MATERIAL/PROCESS CHARACTERIZATION}

665107 Analysis and optimization of thin film photovoltaic materials and device fabrication by real time spectroscopic ellipsometry (Invited Paper) [6651-06]

J. Li, J. A. Stoke, Univ. of Toledo (USA); N. J. Podraza, Univ. of Toledo (USA) and The Pennsylvania State Univ. (USA); D. Sainju, A. Parikh, X. Cao, H. Khatri, Univ. of Toledo (USA); N. Barreau, LAMP, Univ. of Nantes (France); S. Marsillac, X. Deng, R. W. Collins, Univ. of Toledo (USA) 
665108 A reliable optical method for in situ process control for deposition of $\mathrm{Cu}(\mathrm{In}, \mathrm{Ga}) \mathrm{Se}_{2}$ thin layers for photovoltaics [6651-07]

R. Hesse, R. Caballero, D. Abou-Ras, T. Unold, C. A. Kaufmann, H.-W. Schock, Hahn-MeitnerInstitut Berlin (Germany)

\section{SESSION 3 SOLAR CELL MATERIAL/CELL PROCESSING}

6651 OB Textured, doped, ZnO thin films produced by a new process for a-Si and CIGS solar cell application [6651-10]

S. Y. Guo, L. Sahoo, Energy Photovoltaics, Inc. (USA); G. Sosale, McGill Univ. (Canada);

A. E. Delahoy, Energy Photovoltaics, Inc. (USA)

6651 OC PECVD deposition of a-Si:H and $\mu \mathrm{C}-\mathrm{Si}: H$ using a linear RF source [6651-11]

B. B. Van Aken, C. Devilee, M. Dörenkömper, M. Geusebroek, M. Heijna, J. Löffler,

W. J. Soppe, ECN Solar Energy (Netherlands)

6651 OD Correlation between the photoconductivity and the nanostructure of hot-wire deposited silicon-germanium alloys analyzed by anomalous small-angle x-ray scattering [6651-12] G. Goerigk, Institut für Festkörperforschung, Forschungszentrum Jülich (Germany);

D. L. Williamson, Colorado School of Mines (USA)

6651 OF Modeling of Si-based solar cells with V-grooved surface texture by Crosslight APSYS [6651-14]

Y. G. Xiao, M. Lestrade, Z. Q. Li, Z. M. S. Li, Crosslight Software, Inc. (Canada)

\section{SESSION 4 PV MODULE/MANUFACTURING ISSUES}

6651 OG Electrical and photovoltaic properties through a large multicrystalline Si ingot [6651-15]

S. Martinuzzi, I. Périchaud, O. Palais, D. Barakel, Univ. Paul Cezanne-Aix (France);

M. Gauthier, Photowatt Int. SA (France)

$6651 \mathrm{OH}$ Influence of the laser parameters on the patterning quality of thin-film silicon modules

[6651-16]

S. Haas, A. Gordijn, G. Schöpe, B. E. Pieters, H. Stiebig, Forschungszentrum Jülich (Germany)

POSTER SESSION

$6651 \mathrm{OL} \quad$ Fabrication of $\mathrm{Cu}(\mathrm{In}, \mathrm{Al}) \mathrm{Se}_{2}$ solar cells by three-stage evaporation process [6651-20]

T. Hayashi, T. Minemoto, T. Araki, H. Takakura, Ritsumeikan Univ. (Japan)

Author Index

iv 


\title{
Conference Committee
}

\author{
Symposium Chair \\ Ravi Durvasula, Lightfleet Corporation (USA) \\ Conference Chairs \\ Bolko von Roedern, National Renewable Energy Laboratory (USA) \\ Alan E. Delahoy, Energy Photovoltaics, Inc. (USA) \\ Program Committee \\ Robert W. Collins, Jr., University of Toledo (USA) \\ Ravi Durvasula, Lightfleet Corporation (USA) \\ Alan L. Fahrenbruch, Stanford University (USA) \\ Sheyu Guo, Energy Photovoltaics, Inc. (USA) \\ Steven G. Hegedus, University of Delaware (USA) \\ Martha C. Lux-Steiner, Hahn-Meitner-Institut Berlin (Germany) \\ James R. Sites, Colorado State University (USA)

\section{Session Chairs} \\ 1 Solar Cell Operation \\ Alan E. Delahoy, Energy Photovoltaics, Inc. (USA) \\ 2 Solar Cell Material/Process Characterization \\ Bolko von Roedern, National Renewable Energy Laboratory (USA) \\ 3 Solar Cell Material/Cell Processing \\ Robert W. Collins, Jr., University of Toledo (USA) \\ $4 \quad$ PV Module/Manufacturing Issues \\ Neelkanth G. Dhere, University of Central Florida (USA)
}


Downloaded From: https://www.spiedigitallibrary.org/conference-proceedings-of-spie on 26 Apr 2023

Terms of Use: https://www.spiedigitallibrary.org/terms-of-use 


\title{
The Solar-Hydrogen Economy - An Analysis
}

\author{
Warren D. Reynolds CEO, Eco-Engineers, Inc
}

Suite 87, 2700 E. Valley Pkwy, Escondido, CA 92027

\begin{abstract}
The $20^{\text {th }}$ Century was the age of the Petroleum Economy while the $21^{\text {st }}$ Century is certainly the age of the Solar-Hydrogen Economy. The global Solar-Hydrogen Economy that is now emerging follows a different logic. Under this new economic paradigm, new machines and methods are once again being developed while companies are restructuring.
\end{abstract}

The Petroleum Economy will be briefly explored in relation to oil consumption, Hubbert's curve, and oil reserves with emphasis on the "oil crash". Concerns and criticisms about the Hydrogen Economy will be addressed by debunking some of the "hydrogen myths".

There are three major driving factors for the establishment of the Solar-Hydrogen Economy, i.e. the environment, the economy with the coming "oil crash", and national security.

The New Energy decentralization pathway has developed many progressive features, e.g., reducing the dependence on oil, reducing the air pollution and $\mathrm{CO}_{2}$. The technical and economic aspects of the various Solar-Hydrogen energy options and combinations will be analyzed.. A proposed 24-hour/day 200 MWe solarhydrogen power plant for the U.S. with selected energy options will be discussed.

There are fast emerging Solar Hydrogen energy infrastructures in the U.S., Europe, Japan and China. Some of the major infrastructure projects in the transportation and energy sectors will be discussed. The current and projected growth in the Solar-Hydrogen Economy through 2045 will be given.

Table of Contents

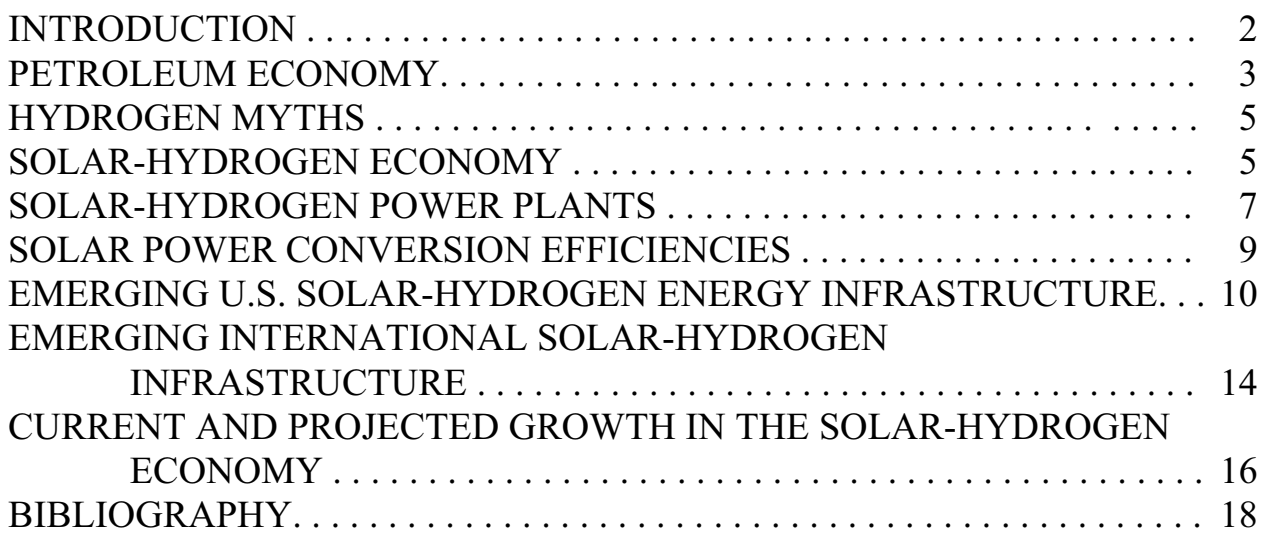

Key words: Hydrogen Economy, Solar Economy, solar energy, wind power, peak oil, solar PV, solar conversion, energy conversion, solar steam, solar Stirling-engine. 


\section{INTRODUCTION}

The $20^{\text {th }}$ century was the age of the Petroleum Economy while the $21^{\text {st }}$ century and beyond is certainly the age of the Solar-Hydrogen Economy. The global Solar-Hydrogen Economy that is now emerging follows a different logic where new machines and methods are once again being invented while companies are restructured. A growing number of mainstream energy companies including Shell and GE are adding new divisions and investing in solar-based technologies ${ }^{1}$.

There is a wealth of information on the rapidly growing Solar-Hydrogen Economy. The areas that I will cover include:

- Petroleum Economy and Coming "Oil Crash"

- Hydrogen Myths

- Solar-Hydrogen Economy

-Factors that drive us to the Solar-Hydrogen Economy

- Solar-Hydrogen Power Plants

- Solar Power Conversion Efficiencies

- Emerging U.S. Solar-Hydrogen Energy Infrastructures

- Emerging International Solar-Hydrogen Energy Infrastructure

- U.S. And World Growth in Solar-Hydrogen Economy

We will briefly inspect the Petroleum Economy and expected "oil crash" which is one of the factors that drive us to the Solar-Hydrogen Economy. We will also look at the other factors.

The main section is the New Energy options and how they are serially dependent. A planned 24-hour/day 200 MWe solar hydrogen power plant will be used as an example.

Further, we will look at the emerging New Energy infrastructures in the U.S. and around the world. Just as a note, the U.S. is lagging behind Europe and Japan in converting to the Solar-Hydrogen Economy. Finally, I will inspect an estimated time-line for the U.S. conversion to the new economy. As a reference and starting point, let us ask the question:

\section{What is the world's total consumption of energy from different sources?}

In 2006, the world's annual energy consumption grew $4.8 \%$ to $431 \times 10^{15}$ BTUs. This rate of growth is estimated to continue for the next 10 years. Petroleum makes up more than $1 / 3$ of the energy consumed mainly for transportation as shown below. If wind power's world growth continues as expected, it will surpass nuclear power in three years as we shall see later. The world's different sources of energy can be broken down as follows ${ }^{2,5,14}$ :

Petroleum $34.3 \%$
Coal $25.1 \%$
Natural gas $20.9 \%$
Nuclear $6.5 \%$
Renewables $4.8 \%$
wind
solar
hydroelectric
geothermal
tidal
biomass


Enormous amounts of carbon-free energy will be required during the coming decades in order to stabilize the atmospheric $\mathrm{CO}_{2}$ to acceptable levels. Solar energy is by-far the largest source of non-carbonaceous energy, globally, and can be used to produce both electricity and fuels ${ }^{2}$

\section{PETROLEUM ECONOMY}

\section{What effect will "peak oil" have on the U.S. and World Economies?}

In 1957, Dr. M. King Hubbert, a U.S. geophysicist working for Shell Oil, developed a method for predicting the lifetime of an oil field from early oil production data ${ }^{12,13,15,16,23}$.

Figure 1 illustrates Hubbert's curve for the oil production output for all of the U.S. oil fields. As you can see, it is a Gaussian-shaped curve. Back in 1957, Dr. Hubbert predicted that the U.S. oil production would peak in 1970. From the Gaussian-curve, U.S. oil production did peak in 1970. It has been in decline since that time. Since 1970, we have had to increase our dependence on foreign oil shown by the blue line. The Prudhoe Bay oil discovery in 1985 just showed a small peak and it, too, has declined $45 \%$ from 1987 to $2007^{24}$.

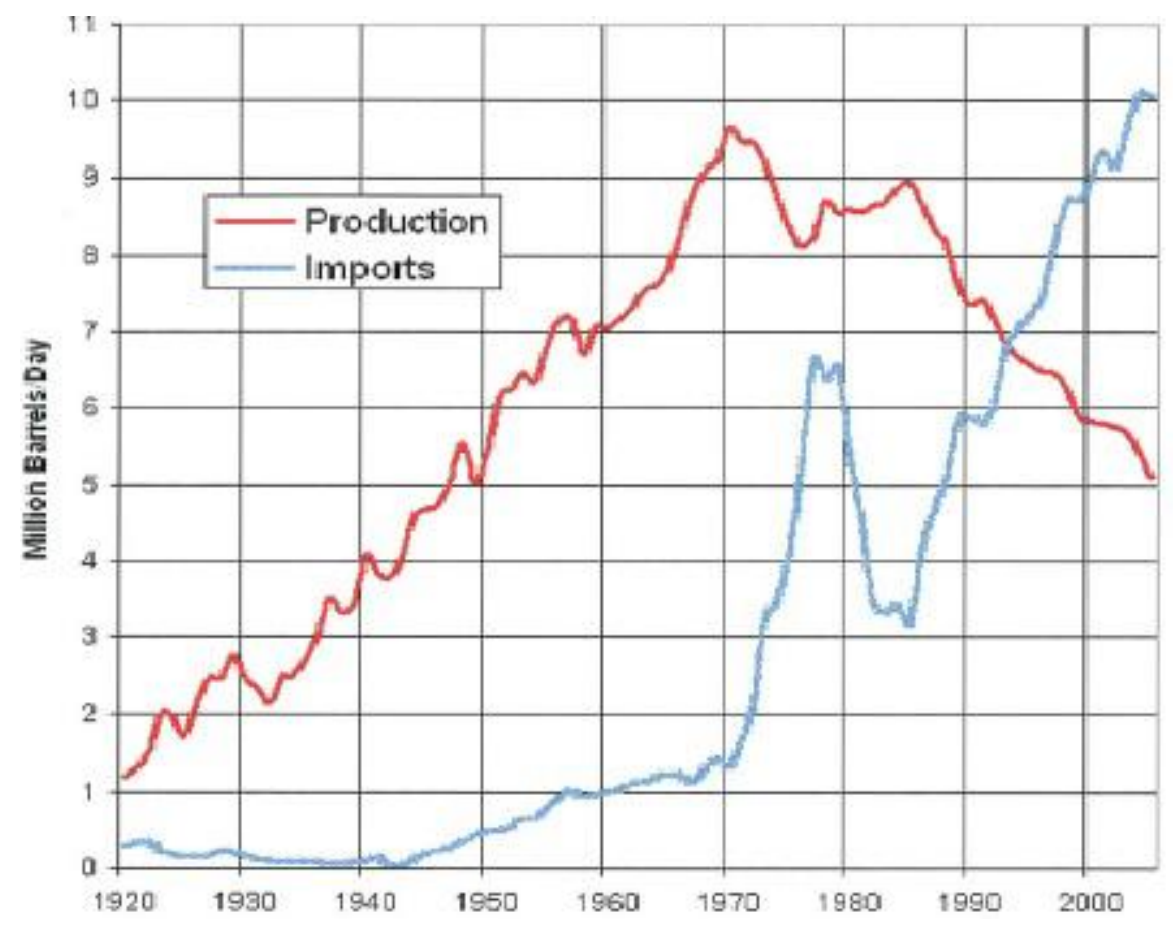

Figure 1. U. S. Oil Production from 1920-2006

In Figure 2 on the next page, we have another example of Hubbert's Gaussian curve applied to Norway's total oil production from 1970 and projected through to 2030. Its oil production peaked in 2001 followed by a decline. All the production data up to 2007 are shown as blue points. It follows the Gaussian curve very closely. I believe that this confirms Mr. Hubbert's theorem ${ }^{25}$. 


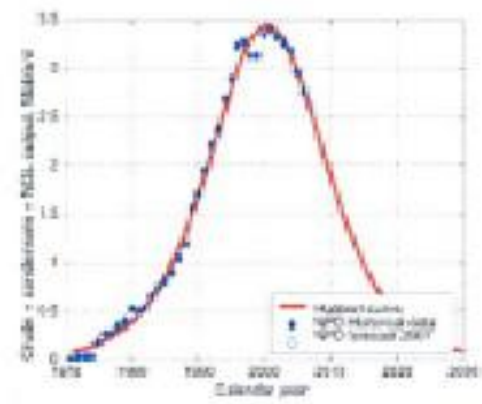

Figure 2. Norway's Oil Production and Forecast

In Figure 3 below, the world's oil production also shows a Gaussian curve with peak total production about 2015. This curve is a summary of the oil production of 42 non-OPEC countries and the 7 major OPEC countries. The 42 countries produce $47 \%$ of the world's oil while $53 \%$ is produced by the OPEC nations. All of the 42 non-OPEC countries oil production have peaked before 2007. China's major oil field peaked in $2000^{28}$ :

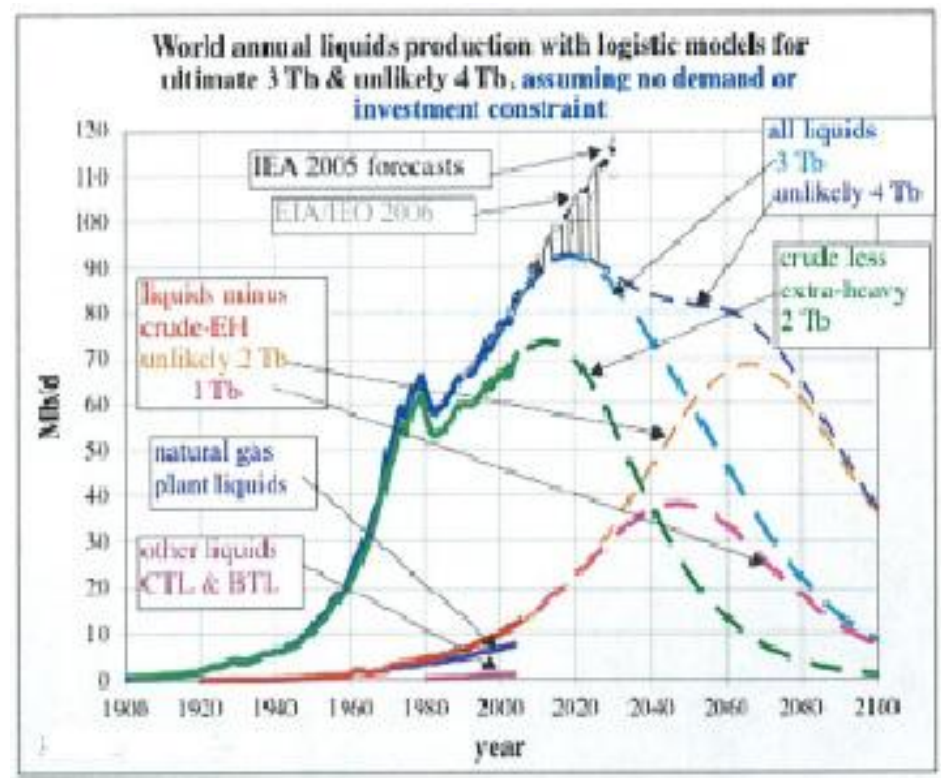

Figure 3. World's Annual Oil Production and Oil Demand

The cross hatch area in Figure 3 is the shortfall between the demand line as represented by the EIA forecast 2006 and the blue production curve. This shows the increasing oil shortage from about 2009 and following years. This world oil shortage ("oil crash") converts into an ever increasing oil price from the current $\$ 62 / \mathrm{bbl}$ to more than $\$ 100 / \mathrm{bbl}$ by 2010. I would expect the price of gasoline in the U.S. to increase to over $\$ 6 /$ gallon by 2010. In Europe in 2006, it was already \$7/gallon in Amsterdam. Consequently, the "oil crash" would destabilize the economies of the world resulting in a deep recession and create a surge toward the Solar-Hydrogen Economy ${ }^{6-8}$.

The oil companies' geologists have searched the world over for oil and none has been found to equal the Saudi fields. The recent (2007) oil discoveries in the Gulf and elsewhere are just a drop in the bucket compared to the Saudi fields. Thus, Hubbert's curve shown in blue above will not change ${ }^{30}$. 


\section{HYDROGEN MYTHS}

What are some of the concerns and criticisms of the Hydrogen Economy ${ }^{29}$ ?

\section{MYTH \#1}

"The Hindenburg disaster was caused by a hydrogen explosion"

Not true. An electrostatic charge accumulated in the silk undercoating and ignited the cotton fabric outer-coating that was composed of a cellulose nitrate polymer mixed with high levels of aluminum powder with iron oxide ${ }^{29,47}$.

Dr. Addison Bain, a NASA hydrogen expert, has spent six years investigating this disaster. From all his research on the eyewitnesses' accounts, the 1937 newsreel movie, testing a small section of original unburned outer blimp fabric, documents at the Hindenburg museum, and reconstructing a miniature blimp, Dr. Bain was able to re-create the chainof-events that triggered the fire. This gave proof that the Hindenburg disaster was initiated by electro-static charge and the resulting outer-covering fire followed by the $\mathrm{H}_{2}$ fire. From the Hindenburg museum documents, he found the laboratory notebook and test results and photos conducted by the German scientists in 1934. The German tests confirmed Dr. Bain's same tests on the Hindenburg fabric material. As a note, a mixture of an aluminum powder and flammable polymer is a recipe for rocket fuel.

\section{MYTH \#2}

"A whole hydrogen industry would need to be developed from scratch"

Not true. It is already a large mature global industry with hydrogen used in many different industries. About $5 \%$ of the U.S. natural gas goes for $\mathrm{H}_{2}$ production from which $45 \%$ of that $\mathrm{H}_{2}$ is used in oil refineries. The $\mathrm{H}_{2}$ industry has a $>50$ year safety record. The current hydrogen usage in the Solar-Hydrogen Economy is now one of local decentralized generation.

\section{MYTH \#3}

"We lack a safe and affordable way to store $\mathrm{H}_{2}$ in autos"

Not true. In 2002, GM tested their 3-layer composite 10,000 psi tank. It is extremely rugged that survived crash tests that flatten steel cars and shred gasoline tanks. These tanks met strict European and U.S. safety standards. The 10gallon tank holds $12 \mathrm{~kg} \mathrm{H}_{2}$ for 300 miles

\section{MYTH \#4}

"Compressing $\mathrm{H}_{2}$ for auto storage tanks takes too much energy"

Not true. Current water electrolyzers generate $\mathrm{H}_{2}$ directly at 10,000 psi without compressors

\section{SOLAR-HYDROGEN ECONOMY}

What are the factors driving us to the Solar-Hydrogen Economy ${ }^{l}$ ? 
- Our Environment, i.e., global warming and air pollution

- Our Economy, i.e., coming "Oil Crash"

- Our National Security, i.e., geopolitical problems in Middle East

The global warming debate is over due to the 2007 report from the International Panel on Climate Change. Global warming is caused by several factors among which is mankind's generation of carbon dioxide. Since the 1990's, the high levels of air pollution in the U.S. and Europe have caused more than 30,000 deaths per year to those who were already throat and lung impaired. The U.S. and Europeans' dependence on foreign oil is a growing concern due to the conflicts in the Middle East ${ }^{1}$.

There are a number of methods for converting and using solar energy. What are some of the Solar-Hydrogen Energy conversion options?

- Wind power

- Solar-steam

- PV cells

- Solar Stirling engine

- Solar-thermoelectric

- Fuel cell

- Tidal - thermal and motion

- Solar-Compressed air

- Direct $\mathrm{H}_{2}$ Combustion

- Biomass ?

- Nuclear power?

As shown above, in the New Solar Economy, we have a number of options for generating, storing and conversion of electricity. As far as biomass and nuclear power is concerned, some solar energy advocates have included them in their list. We will explore these two energy options in detai ${ }^{3,19,31}$.

Since biomass is a renewable energy source, why shouldn't it be included in the Solar-Hydrogen Options?

The advantage that advocates cite is the fact that whether it is burned directly or converted to fuel ethanol all the $\mathrm{CO}_{2}$ generated is taken up by new growing plants with a net zero accumulation. However, what they don't tell you is the fact that the $\mathrm{CO}_{2}$ has a long atmospheric half-life of greater than 10 years and there is a net secular accumulation of $\mathrm{CO}_{2}$ that adds to the global warming. The other disadvantage is that the U.S. does not have sufficient crop-land to generate all the needed bioethanol for all of our 250 million autos 5 .

Why shouldn't nuclear power be included in the Solar-Hydrogen Energy options?

As recently as the 1970 's, it was universally agreed that nuclear power was the energy source for the future. It was anticipated in the 70's that thousands of these would be built with capacities as high as 4,000 MW according to the International Atomic Energy Agency ${ }^{1,17,18}$.

The previous 10 years (1970-1980) had been marked by frequent technical mishaps, serious accidents, huge cost escalations and a rapid decline in public acceptance of nuclear power. 
Since 1978, over 18 European countries have voted to oppose, phase-out or stop nuclear programs. Today, nuclear power has fallen far short of expectations. Just 343 gigawatts of nuclear power are actually in use, which is $<1 / 10$ th of the amount expected ${ }^{1}$.

In the late 1980s-early 90s, the Three-Mile Island, Chernobyl and Monju breeder (Japan) nuclear accidents testify that the use of nuclear power is not a viable option for the future. In addition, the high cost of nuclear generation of electricity and today's high cost of nuclear plant construction are no longer economically attractive $\mathrm{e}^{11,17}$.

The many reasons for the collapse of nuclear power systems include ${ }^{1}$ :

- safety problems

- inability to dispose of nuclear waste

- potential uncontrolled proliferation of nuclear materials in the hands of terrorists

- highest cost for generating electricity (11.4-14.5 cents/kWhr) of all fossil fuels and most all of the renewable energy sources.

- during the period 1985-2007, there was a huge cost escalation from $\$ 1$ billion to more than $\$ 9$ billion for the same size nuclear plant

\section{SOLAR-HYDROGEN POWER PLANTS}

What is the general lay out of a 24-hour/day solar-hydrogen power plant?

The structuring of a 24-hour/day solar-hydrogen power plant for the conversion of the sun's energy into electric power for both day and night use encompasses three consecutive sections or units. These three phases or units can be designated as "A-B-C". The "A" component or unit is used to convert the sun's energy into electric power either directly or indirectly, i.e., thermally. The "B" unit is the storage of some of the sun's converted electric energy for night time use. The " $\mathrm{C}$ " unit is the conversion of the stored energy back into electric power for night time use for the power grid.

\section{TABLE I. Solar Energy Options}

\author{
"A" OPTIONS \\ Energy Conversion \\ - PV cell \\ - Solar Stirling engine \\ - Solar-steam \\ - Wind power \\ - Thermoelectric \\ - Solar-air compression
}

\author{
"B" OPTIONS \\ Energy Storage \\ - Hydrogen \\ - Compressed air \\ - Batteries \\ - Capacitors \\ - Flywheel
}

\author{
"C" OPTIONS \\ Stored Energy Conversion \\ - Hydrogen \\ -HICE co-gen \\ -Fuel cell \\ -Combustion co-gen \\ - Compressed air turbine \\ co-gen.
}

How are the combinations selected for structuring a 24-hour/day solar power plant?

As shown above, there are many options for each of the consecutive A-B-C units. For example, we could select $P V$ cell - compressed air - air turbine as the three units. Another example would be solar Stirling engine - hydrogen - 
combustion co-generation. However, selection of each correct separate unit and its compatibility, i.e., sizing, with each of the succeeding units must be taken into account. The overall efficiency of the selected consecutive A-B-C units must also be maximized while the economic viability of these same three units must be minimized. Thus, the pathway for achieving the maximum efficiency at minimum cost is a complex task under current technology. However, as technology improves, new innovations develop, and price reductions occur over time then it becomes even more obvious what that pathway will be in the future.

There are a number of "A" options for the conversion of the sun's energy either directly or indirectly into electric power. For the direct conversion of solar energy into electric power, there are only two major methods. The indirect conversion of solar energy can also be accomplished by at least three methods. Some of these methods are commercially available with prices falling.

Once the electricity is generated from the sun then some of that energy can be used for the grid electric power while the balance of that energy is stored and reclaimed for night time use from the " $\mathrm{B}$ " unit. The " $\mathrm{B}$ " unit can be configured by three major different approaches. The storage of electric energy can be done as either chemical or physical potential energy. For large solar power plants, the most useful form for energy storage is hydrogen.

For the "C" unit or conversion of stored power back into electricity can be accomplished by a number of commercially available systems. Stationary hydrogen fuel cells have been used in a number of small $<5 \mathrm{MWe}$ applications. GE is developing a hydrogen-turbine power generator.

What is the estimated cost and land area for the different 24-hour/day 200 MWe solar-hydrogen power plants using the solar options?

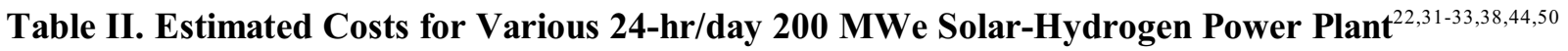

\begin{tabular}{|l|c|c|}
\hline $\begin{array}{l}\text { TOTAL A-B-C SOLAR POWER } \\
\text { SYSTEM }\end{array}$ & $\begin{array}{l}\text { Estimated Cost }(2010) \\
\text { without land cost }\end{array}$ & Required Land Area \\
\hline Wind Farm* & $\$ 333.86$ million & 85 Acres \\
\hline Concentrated Solar-Stirling Engine & $\$ 370.06$ & 1,200 \\
\hline $\begin{array}{l}\text { Concentrated Solar-Compressed Air } \\
\text { (no hydrogen) }\end{array}$ & $\$ 340.26$ & 1,100 \\
\hline Solar-Steam/Tesla turbine & $\$ 343.86$ & 1,200 \\
\hline Concentrated Solar-PV Cells & $\$ 734.90$ & 1,500 \\
\hline
\end{tabular}

* Includes B and C units for hydrogen electrolysis production, storage, and combustion back to electric power (\$133.86 million). The concentrated solar-compressed air does not require $\mathrm{H}_{2}$ for energy storage as the compressed air can be stored in caverns below ground and retrieved at night to generate electricity for the $\operatorname{grid}^{32,35}$

The first four 24-hr/day solar-hydrogen systems costs are approximately $1 / 6$ th the cost of a $200 \mathrm{MWe}$ nuclear plant ${ }^{32}$. 


\section{SOLAR POWER CONVERSION EFFICIENCIES}

Solar conversion efficiency is important. Selection of a group of energy conversion units for an A-B-C combination to make a total system is based on the conversion efficiency of each unit whether it is solar-into-electricity or hydrogeninto-electricity.

Which of the different solar power converters has the highest efficiency?

From the previous A-B-C options list of solar power converters, stored power generation and conversion, a number of these solar power converters, their conversion efficiencies (2007) and their theoretical conversion efficiencies' limits, are included in the table below:

Table III. Solar Energy Conversion Efficiencies ${ }^{4,20,21,41,42,53,64,65,67,69}$

\begin{tabular}{|c|c|c|}
\hline SOLAR UNIT & $\begin{array}{l}\text { UNIT EFFICIENCY } \\
(2007)\end{array}$ & $\begin{array}{l}\text { THEORETICAL } \\
\text { LIMIT }\end{array}$ \\
\hline $\begin{array}{l}\text { Reflective solar - Stirling engine (no } \\
\text { combined heat and power) }\end{array}$ & $38 \%$ & $\operatorname{Carnot} \frac{\left(\mathrm{T}_{2}-\mathrm{T}_{1}\right)}{\mathrm{T}_{2}} \quad(80 \%)$ \\
\hline $\begin{array}{l}\text { Fresnel lens(200x)-solar steam (no } \\
\text { combined heat and power) }\end{array}$ & $35 \%$ & $\operatorname{Carnot} \frac{\left(\mathrm{T}_{2}-\mathrm{T}_{1}\right)}{\mathrm{T}_{2}} \quad(52 \%)$ \\
\hline Wind power & $15-25 \%$ & Betz Law $\quad(59 \%)$ \\
\hline Thermoelectric (Seebeck effect) & $5-6 \%$ & $\lim \frac{\left(T_{2}-T_{1}\right)}{T_{2}} \quad(30 \%)$ \\
\hline Hydrogen - Fuel Cell & $72 \%$ & Nernst Law $(95 \%)$ \\
\hline PV Cells - pure Si & $18 \%$ & S-Q Theory $\quad(31 \%)$ \\
\hline -Fresnel lens $(200 x)$ - pure Si & $30 \%$ & ------- \\
\hline-2 junction & ----- & lab $30 \%$; theory $43 \%$ \\
\hline $\mathrm{In}_{1-\mathrm{x}} \mathrm{Ga}_{\mathrm{x}} \mathrm{N}$ full spectrum & ------ & lab 30\%; Theory $80 \%$ \\
\hline
\end{tabular}

Of the currently available indirect solar conversion methods, both the solar-steam and solar-Stirling engine have about the same efficiency. Choice becomes a matter of economics. The InGaN method is a new approach to solar energy conversion. It is not an alloy but a "sea" of InN with homogeneous amounts of GaN. Figure 4 on the next page shows a full spectrum of this mixed compound energy converter. In Figure 4, the point at $2.0 \mathrm{ev}(0 \% \mathrm{Ga})$ was the original literature band-gap value for InN. The Lawrence Berkeley lab group re-measure the band-gap and found a different level of around $0.4 \mathrm{ev}$. The group tested various mixtures of $\mathrm{InN}$ mixed with $\mathrm{GaN}$ together and found a range of bandgap values from 0.4 to $3.3 \mathrm{ev}$, or covering the full visible spectrum ${ }^{39,49}$ : 


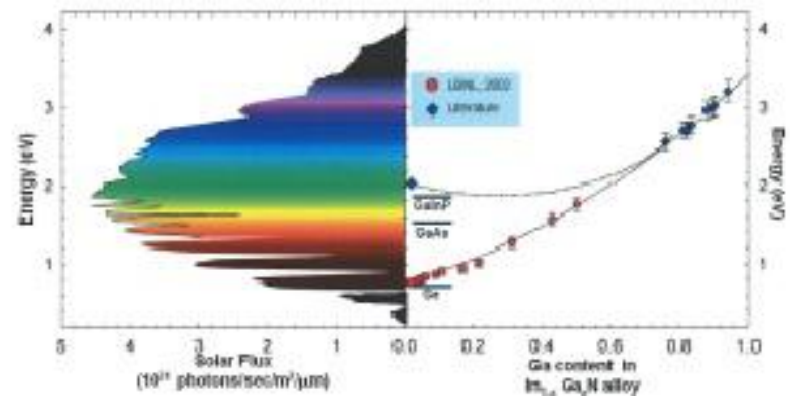

Figure 4. Full Spectrum of Nitrides

This new approach shows promise for solar energy conversion.

\section{EMERGING U.S. SOLAR HYDROGEN ENERGY INFRASTRUCTURE}

What is the total U.S. energy consumption?

In 2006, the U.S. consumed $102.7 \times 10^{15}$ BTUs of energy. This represents $23.8 \%$ of world's energy consumption. The U.S. population of 300 million people spent slightly more than 1 trillion dollars on energy alone which is more than 8 $\%$ of the gross national product. Currently, only $4 \%$ of this $\$ 1$ trillion was spent on renewable energy ${ }^{1,14}$.

What are some of the newer solar energy projects in the U.S.?

A few of the March 2007 U.S. solar energy projects are listed below ${ }^{54,57,87}$ :

- Arizona: 5 MWe PV project completed near Phoenix

- Texas: USAF issues RFP for $1 \mathrm{MWe}$ PV system

- Florida: Dana City plans $\$ 1.08$ million PV system for streetlights

- California: Lennar Homes starts to build largest PV solar homes project in the U.S.

- California: Google, Inc. completes 1.6 MWe PV array system on it's headquarters building

- Plus 20 other project

- California - $75 \%$ of U.S. solar market

In 2007, there are a lot of small solar energy projects ongoing. This is just the March 2007 summary of projects in the U.S. ${ }^{100}$

In the past three years, there were three notable solar projects. The first is the totally designed solar-hydrogen home completed in 2006 in Scottsdale Arizona. Also in 2006, the ISE Corporation (California) received Government funding to build $15 \mathrm{H}_{2}$ fuel cell buses. In 2004, the Palm Desert California SunLine Transit company uses the first $\mathrm{H}_{2}$ internal-combustion-engine bus ${ }^{1,56,90}$.

Are there any large-scale solar projects being planned for the U.S.?

Yes, there is a large-scale solar energy project completed and others are under construction in Nevada and California. 
In early 2007, a 64 MWe solar-thermal power plant was completed near Boulder City, Nevada. Figure 5 below shows the construction of the $64 \mathrm{MWe}$ solar power plant during $2006^{9,10}$ :

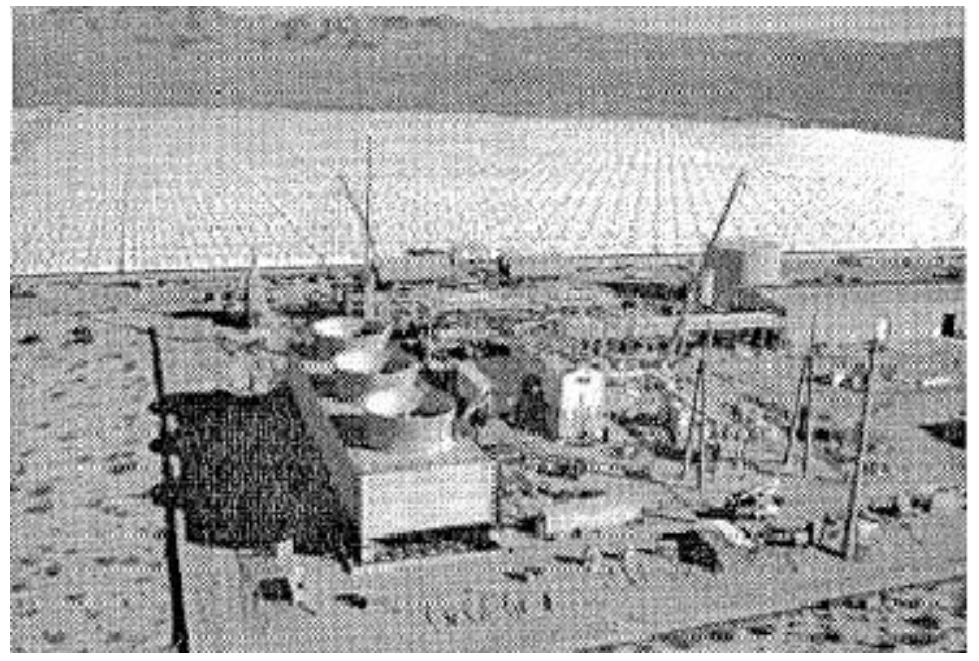

Figure 5. 64 MWe Solar-Thermal Power Plant Project Under Construction

The 64 MWe system is composed of aluminum trough reflectors focused on pipes that contain high boiling point oil. The oil is heated to over $300^{\circ} \mathrm{C}$ and pumped to the boiler unit where steam is generated

In California there are two solar-thermal projects planned with one under construction that are the largest in the world. Both of these projects are reflective solar Stirling engine projects to be located in Los Angeles and San Diego. In 2005, the Stirling Energy Systems Corporation signed contracts with two California electric power companies. One with Southern California Edison Electric and the other with San Diego Gas \& Electric. The first phase of the San Diego project is partially completed. The details are $\mathrm{e}^{34,36,40,43,55}$ :

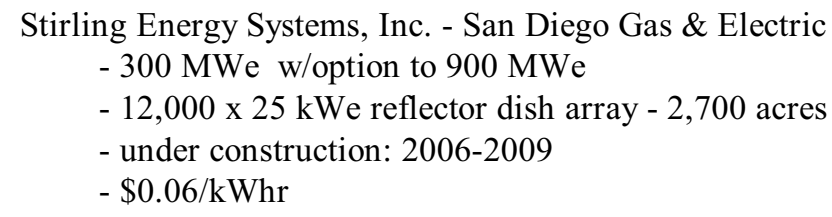

Stirling Energy Systems, Inc. - So. California Edison Electric - $500 \mathrm{MWe}$ w/option to $850 \mathrm{MWe}$

$-20,000$ X $25 \mathrm{kWe}$ reflector dish array - 4,500 acres

$-2009-20012$

- $\$ 0.06 / \mathrm{kWhr}$

Figure 6 on the next page shows many of the reflective solar-Stirling engines already installed during Phase I at the San Diego Gas \& Electric solar power plant ${ }^{55}$ : 


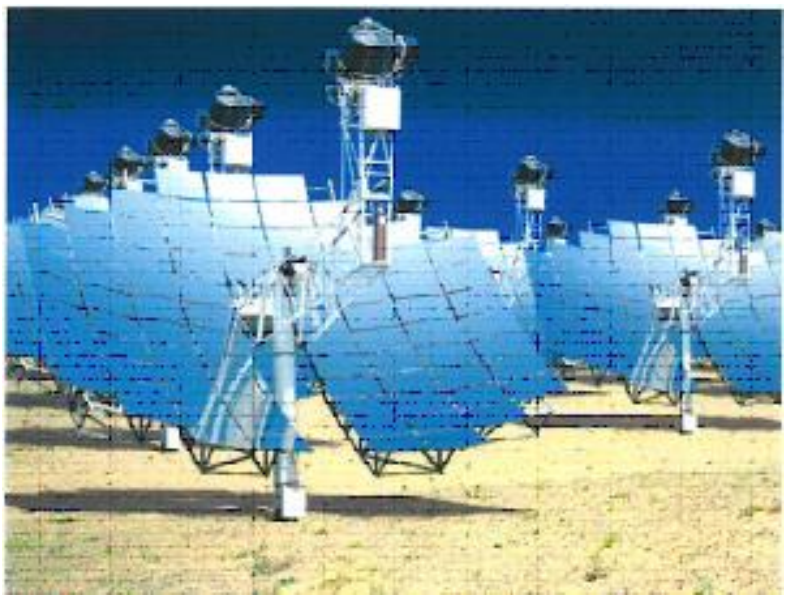

Figure 6. A group of reflective solar-Stirling engines (Phase I) at the San Diego Gas \& Electric solar power plant area

All of these previous solar power plants are for daytime energy generation. Will there be any full 24hour/day solar hydrogen power plants built in the U.S. ?

Yes, there are several full 24-hour solar-hydrogen power plants planned for the U.S. A typical example is shown:

Table IV. 200 MWe 24-Hour/day Solar-Hydrogen Power Plant ${ }^{32,36,37,48,71,72}$

\begin{tabular}{|l|c|c|}
\hline \multicolumn{1}{|c|}{$\begin{array}{c}\text { Components } \\
\text { A-B-C }\end{array}$} & $\begin{array}{c}\text { Cost 2009 (est.) } \\
\text { \$ million }\end{array}$ & $\begin{array}{c}\text { Required Land } \\
\text { area }\end{array}$ \\
\hline Combined 150 MWe wind farm and & 283.86 & 64 acres \\
\hline $\begin{array}{l}\text { 50 MWe Concentrated Solar } \\
\text { Stirling Engine }\end{array}$ & 192.91 & 450 acres \\
\hline Total 200 MWe Solar-Hydrogen System & 476.77 & 514 acres \\
\hline
\end{tabular}

* Day time output: total $200 \mathrm{MWe}$ with $150 \mathrm{MWe}$ to power grid and $50 \mathrm{MWe}$ goes to the electrolyzer for $\mathrm{H}_{2}$ production and stored.

\section{What is the U.S. installed wind power capacity?}

A study has shown that cost of electricity drops with wind speed to as low as $\$ 0.026$ at $30.1 \mathrm{miles} / \mathrm{hr}$. In addition, improvements in wind turbine design also bring down the costs. Some of the newer developments have been in vertical wind turbines ${ }^{51,72}$.

A number of studies have been done on converting wind power electricity directly to $\mathrm{H}_{2}$. A large wind-to- $\mathrm{H}_{2}$ facility has been completed and in operation for the North Dakota Basin Electric Power Cooperative. The generated $\mathrm{H}_{2} \operatorname{cost}$ is about $\$ 2.42 / \mathrm{kg}$. Wind power has an advantage since North Dakota has fairly good wind speeds at all hours ${ }^{1,45,70}$.

Figure 7 on the next page shows a State-by-State summary of the total installed wind capacity as of $2006^{59}$ 


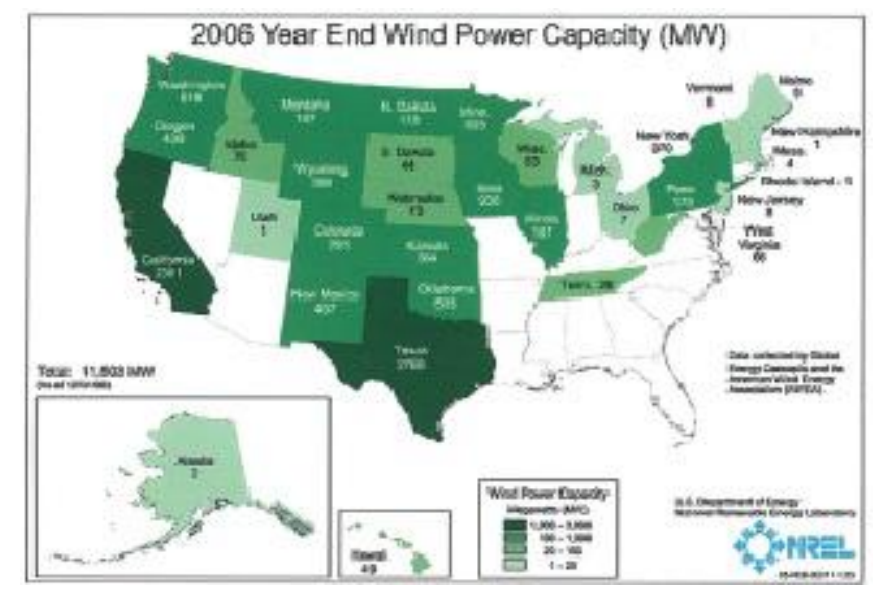

Figure 7. U.S. State-by-State Total Installed Wind Capacity - 2006

The U.S. wind power has grown fourfold since 2000 and now has a total capacity of 11,603 . Texas leads the U.S. in windpower production with California a close second. California obtains $2 \%$ of its electrical needs from windpower.

\section{How extensive is the U.S. conversion to $\mathrm{H}_{2}$ transportation infrastructure?}

Both the $\mathrm{H}_{2}$ fueling stations and the hydrogen auto infrastructure projects are rapidly moving forward into commercialization. California leads the nation in moving toward having $\mathrm{H}_{2}$ fueling stations in large cities and major roads. ${ }^{62}$

In 2004, Governor Schwarzenegger signed into law a "Hydrogen Highway" program. Its goal is having 200 fueling stations located every 20 miles along four major north-south highways, i.e., Interstate $\underline{5}, \underline{10}, \underline{15}$, and $\underline{80}$. In 2006, there were already $21 \mathrm{H}_{2}$ fueling stations in Los Angeles with 10 more planned with local $\mathrm{H}_{2}$ production. In San Francisco and Sacramento, there are 11 with 10 more planned. All with local $\mathrm{H}_{2}$ production. ${ }^{1,60}$

"Big Oil" and the automotive industries are actively engaged in providing a foundation for the $\mathrm{H}_{2}$ infrastructure. In 2006, Rick Zalesky, Chevron's Hydrogen Boss, stated that "Hydrogen is not like petroleum or natural gas, or anything else we've done before." "Old ways do not work", i.e. a centralized fueling network. Thus, "Big Oil" will have to dismantle its fuels' distribution network. ${ }^{1}$

In 1996, Ford had the right idea for introducing hydrogen to the consumer by building a small 2.4 liter 4- cylinder hydrogen internal combustion engine (HICE). In 2004, Ford further developed and built more than fifty $235 \mathrm{hp} \mathrm{6.8-}$ liter V-10 cylinder $\mathrm{H}_{2}$ engines and put some of these in shuttle buses. These engines were $25 \%$ more fuel efficient than the gasoline type.$^{63}$ In 2006, thirty of these buses were lent for testing in Florida and California. ${ }^{58,63}$

In 1995, GM threw out its "automotive thinking" and has built several different prototype fuel cell autos. During 20022007, GM developed and tested several more different FC autos. One was the "Hy-Wire" that was radically new in driver functional controls with no pedals and no dashboard. It has a lever-type steering wheel, i.e., airplane type "joy stick". All the control components, fuel cell and electric motor systems are in a 11-inch "skate board" sized chassis between the wheels. The body shell can be mounted in about 3 hours over the chassis. In 2007, GM developed "Equinox" with same FC system as "HydroGen3". GM built 15 of these and is currently testing these FC autos in New York City. ${ }^{61,97}$

All the other major auto manufacturers such as Daimler, Honda, Hyundai and Toyota all have fuel cell autos with more 
than 100 being road tested. Honda has targeted to have 50,000 of their fuel cell auto, FCX-3, on the road by $2012 .{ }^{97}$

In comparing the different auto propulsion systems, what are the various auto "well-to-wheel" efficiencies?

AUTO “WELL-TO-WHEEL" EFFICIENCIES

- Oil well-to-wheels (internal combustion engine) $14 \%$

- Oil well-to-wheels (hybrid) $22 \%$

- Natural gas well-to-hydrogen-wheels (fuel cell auto) $42 \%$

- Water-well-to-hydrogen-wheels (fuel cell auto) $44 \%$

The water-to-hydrogen auto efficiency is better than our current petroleum-based autos. Not only is the fuel cell auto more environmentally helpful but it is also more also more fuel efficient. ${ }^{1}$

\section{EMERGING INTERNATIONAL SOLAR-HYDROGEN INFRASTRUCTURE}

\section{Iceland}

\section{Will Iceland adapt to the Hydrogen Economy?}

Yes, even though Iceland has plenty of low cost geothermal electric power, in 2000, Iceland was the first country to commit totally to hydrogen power. Iceland's President Grimsson stated: "The whole nation is converting to hydrogen power". "We are making Iceland a trial base to see what can develop for our global society.",1,4

By 2006, four Mercedes-Benz fuel cell buses in Reykjavik had traveled over 90,000 km in all types of weather. The engineers were surprised at how well the fuel cell performed with very little maintenance. They are planning for seven more $\mathrm{H}_{2}$ fueling stations and more buses. At Iceland's Deflavik airport, a Plug Power Company "GenCore" stationary $\mathrm{H}_{2}$ fuel cell is being used as back-up power supply. ${ }^{1}$

\section{Denmark}

Denmark has been a pioneer in developing wind power since the 1970s. In 2003, Denmark built the world's largest offshore wind farm of $166 \mathrm{MWE}$ at Lolland. In 2005, they added an additional 916 MWe wind power capacity. By the end of 2006, they had a total of 3,136 MWe total installed. Currently, their total wind power meets $29 \%$ of their electrical needs. Today, $90 \%$ of the wind turbines manufactured in Denmark are sold to international markets capturing $43 \%$ of the world's wind turbine market. ${ }^{84,95,96}$

\section{Europe}

A lot more progress has been made in Europe over the past 20 years than in the U.S. in converting to the New Energy. Starting in 1977, the International Energy Agency established a $\mathrm{H}_{2}$ program with 15 European member nations. The mission was to accelerate $\mathrm{H}_{2}$ implementation and widespread use of $\mathrm{H}_{2}$. By 2001, Europe already had more than $6 \%$ of its energy economy invested in solar energy. ${ }^{78,}$

What are some of the major changes and the current status of Europe's Solar-Hydrogen infrastructure?

In 2006 alone, there were 70 ongoing $\mathrm{R} \& \mathrm{D}$ projects as well as designating two billion euros for the " $\mathrm{H}_{2}$ Vision Program" ( $\$ 2.4$ bn.). Today, Europe produces 3.3\% of its electricity by wind power. A target of $22 \%$ of electricity consumption from solar energy sources by 2010 was set by the European Commission for its 15 members. ${ }^{82,98}$ 
Germany has become Europe's leader in converting to the Solar-Hydrogen Economy. This is due to the German Renewable Energy Law that takes subsidies away from fossil fuels toward solar energy.

\section{Europe's Wind Market - 2006}

The global wind market grew 32\% over 2005 with 15,197 MWe added in 70 countries making the total global installed wind power of 74,223 MWe. Europe's wind energy market continued their rapid growth by adding $50 \%$ of the previous 15,197 MWe making 2006 another record year. ${ }^{80,82}$

In 2006, there was a total of 7,588 MWe of additional wind power installed in eighteen European countries which is a $23 \%$ increase over 2005. Germany alone installed 2,233 MWe bringing their total now over 20,621 MWe. This latter amount is twice that of the total installed U.S. wind power. England had added $168 \mathrm{MW}$ to bring their total to 2,000 MW while Poland's goal is to have a 1,100 MWe wind farm by $2010{ }^{85,86}$

\section{Europe Photovoltaic (PV) Market - 2006}

The global PV market grew 19\% with 1,744 MWe added worldwide Europe continues to lead the world in PV array installations. ${ }^{80}$

In early 2006, Germany added $960 \mathrm{MWe}$ PV power to the grid which is a $16 \%$ growth over the previous year. A U.S. company, First Solar, Inc. has started a 30-month contract (\$171 million) with completion in 2009 to provide $40 \mathrm{MWe}$ of PV panels for installation near Brandis, Germany which will be the world's largest PV solar plant. Spain has started construction of a 6.5 MWe PV array with completion by 2008. In 2006, the Czech Republic's 0.6 MWe PV array went on-line..$^{92,93}$

\section{Europe's Hydrogen Bus Programs}

Since 2003, five European cities have had nine hydrogen buses in operation Amsterdam has had three fuel cell buses in operation with the hydrogen produced by electrolysis at the station. Bus passengers have become $\mathrm{H}_{2}$ advocates. ${ }^{1,78}$

In 2006, the European Commission started the "Hydrogen for Transport" program as a total European effort. ${ }^{88}$ The program's goal is 47 hydrogen buses in 10 cities. Both hydrogen ICE and fuel cell buses are planned. As part of this program, a Luxembourg fuel cell bus built by Mercedes-Benz has experienced 5,000 hours of street operation by the end of 2006. ${ }^{91}$ In addition, Berlin placed two hydrogen internal combustion engine (HICE) buses in service: ${ }^{89}$

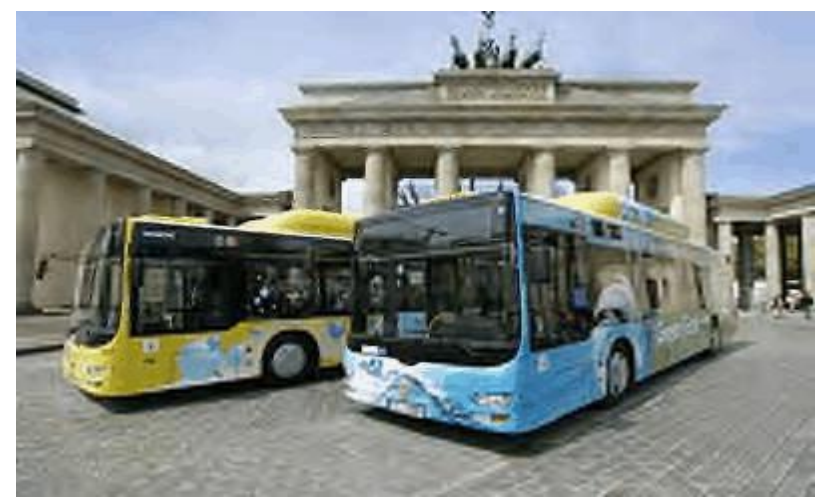

Figure 8. Two Hydrogen Internal Combustion Engine Buses in Berlin, Germany 
In summary, as a result of all the solar projects in Europe, 15 of these countries, mainly Germany, Finland and Netherlands, have brought their total greenhouse gas emissions, $\mathrm{CO}_{2}$, to $1.5 \%$ below 1990 levels. In addition, with the increasing economic growth in Europe in 2007, the previously planned and new Solar-Hydrogen energy projects will keep ahead of the future energy demand.

\title{
Japan
}

What is the status of the PV market in Japan?

Due to Japan's lack of major fossil fuel sources, they started early in solar energy use. The Japanese home owners started 15 years ago to install PV cell systems and today over $80 \%$ of existing homes have installed PV arrays. In 1997 , the Government PV rebate program started with $\$ 3,400 / \mathrm{kW}$ with a limit of $10 \mathrm{kw}$ installed. During the period $1997-2005$, the rebate was gradually reduced to $\$ 200 / \mathrm{kW}$ and, finally, replaced with low interest rate loans. ${ }^{79}$

In 2004, their total sales of manufactured PV units were $\$ 3.07$ billion with about $50 \%$ of this amount was exported. Today, Japan is the largest PV cell producer and the second largest user worldwide (Germany is the first). There is a forecast of 2.35 gigawatt PV sales in 2008 which are $360 \%$ more than $2004 .{ }^{77}$

By 2006, 65\% of the Japanese municipal Governments had already installed PV systems with another 24\% who will install them during 2007-2009 for schools, municipal office buildings, street lights and other Government projects. ${ }^{79}$

Honda Motor built a new PV factory in 2006 and began mass production of the CIGS type PVcells for home use. These sell for $25 \%$ less than the silicon PV cell but are only $12 \%$ efficient. ${ }^{81}$

Japan was also early in wind power use. Due to their large PV usage, the wind power installed capacity was small. In 1999 , they only had 43.4 MWe of installed wind capacity. By 2006, it had grown to $102 \mathrm{MWe}$. Their goal is to have more than 300 MWe by $2010 .{ }^{66}$

\section{China}

China now consumes $14.7 \%$ of the world's energy. Over the past three years this has grown by $65 \%$. China has some of the most polluted cities in the world and will shortly become the largest greenhouse gas emitter by $2010 .{ }^{74}$

In 2006, The Chines Government's Renewable Energy Law was established with a goal of 10\% solar energy by 2020 . This $10 \%$ is an almost impossible goal; however, with their current 103 million square meters of installed solar-heat panels and growing it may be achievable. In addition, China's solar power generation was only $10 \mathrm{MWe}$, a tiny fraction of the 2.83 billion megawatts $\left(10^{15}\right.$ watts) total demand. China's immediate goal is to have $300 \mathrm{MWe}$ solar energy by 2010. Two-thirds of China's land area receives annually more than 2,000 hours of sunlight which is more than other regions of same latitude including Europe and Japan. ${ }^{73-75}$ China is fast becoming a leader in wind technology. ${ }^{68}$

China has 150 PV manufacturers accounting for $1 / 3$ of the world's silicon PV production. Because of the low incountry demand, $90 \%$ of that production was exported. These PV manufacturers are ramping up production to meet China's internal demand. ${ }^{75}$

\section{CURRENT AND PROJECTED GROWTH IN SOLAR HYDROGEN ECONOMY}

\author{
What has been the largest growth areas in the Solar-Hydrogen Economy?
}


World's wind energy market grew $25.6 \%$ over 2005

valued at $\$ 13.4$ billion representing 15,197 MWe added

for a total of 73,900 MWe installed. .2,83 $^{52,197}$

World's solar PV market grew 19\% over 2005 valued at $\$ 10.6$ billion representing $1,738 \mathrm{MWe}$ added for a total of 3,689 MWe installed..$^{99}$

World's solar Stirling engine market grew 40 -fold valued at $\$ 1.3$ billion representing 800 MWe added. ${ }^{34}$

The combined MWe of these three markets added in one year is equal to 35 each 500 MWe nuclear power plants. However, the world wide Solar-Hydrogen Economy is at a critical turning point and is accelerating rapidly showing that substitution of nuclear and fossil energy is possible and necessary. This growing shift to this New Economy is profound. The world will be freed from its dependence on oil and its geopolitical problems of the last 50 years. Thus, the time is long past to set aside the multiple political and structural barriers against the Solar-Hydrogen Economy and to move quickly into this New Economy.

\section{How long will it take to the U.S. to restructure the Petroleum Economy into the Solar-Hydrogen Economy?}

This is a difficult question. The transition to the Solar-Hydrogen Economy is dependent on how fast we can mobilize industry and Government to restructure the Petroleum Economy and how many dollars are put into the transition.

There is a way to estimate the length of time. Interestingly, there is a general curve that governs change in many processes both in science and human phenomenons. It is called the "logistic" or sigmoid curve. For example, the total U.S. energy expenditures would be a good measuring tool for the transition time. Our total energy expenditures were $\$ 1,008$ billion (2006) and represents about $8 \%$ of our GNP. For discussion, this logistic model can be developed as a time vs. Solar-Hydrogen Economy growth. Figure 9, shown below, illustrates a possible time line for the transition: ${ }^{1}$

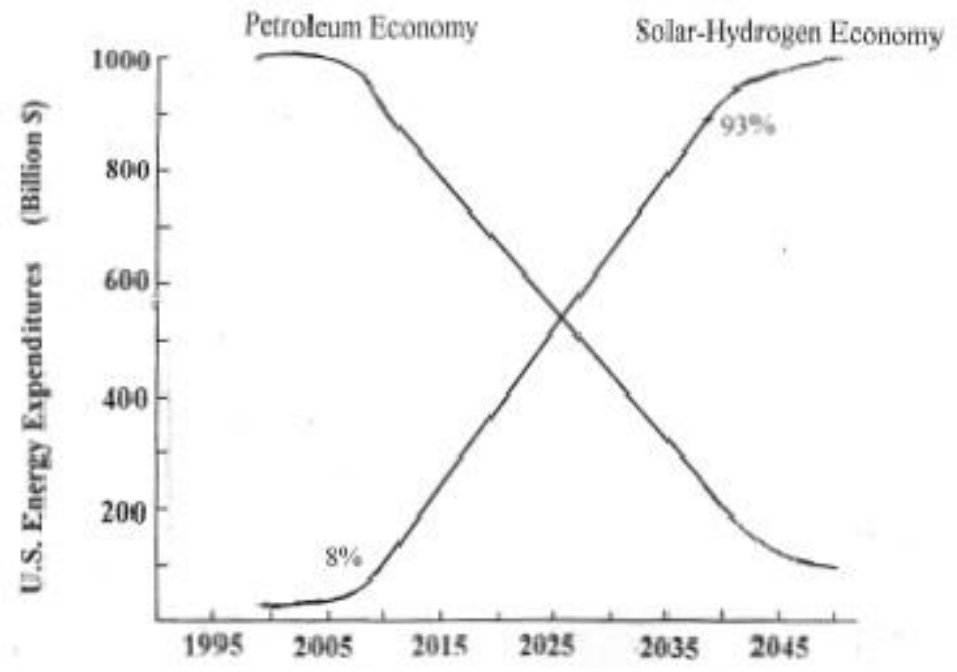

Figure 9. Estimated Time-Line for Conversion to the Solar-Hydrogen Economy 
Currently in the U.S., we are at the 3.5\% renewable energy expenditure level which is just at the "toe" of the exponential growth on the Solar-Hydrogen Economy curve. I would expect the linear portion to start at 8\% (2012) and continue until $93 \%$ is reached. At that point, it will level off asymptotically until we reach a maximum. You will notice that the Petroleum Economy curve finally levels off at $\$ 100$ billion. We will still need some petroleum products such as lubricants and plastic monomers until the renewables can overtake these areas. For the Solar-Hydrogen curve, a $3 \%$ per year linear growth would take 28 years (then 2040) to reach the $93 \%$. I believe a $3 \%$ growth is realistic.

Subsequently, Honda has announced that it will have 50,000 fuel cell cars on the road starting in 2012.This confirms my earlier estimate of 2012 for reaching the $8 \%$ growth.

There is one key obstacle that will delay the Solar-Hydrogen economy from reaching the $8 \%$ point and that is the cost of the fuel cell for autos. Figure 8 assumes that the fuel cell cost will be economically viable by 2012 and the linear growth would start. But, if the recent developments in fuel cells, i.e., polymers, take 8 years to be translated into fuel cells at a lower price, then it would be 2015 before we reach the $8 \%$ mark. Thus, it would be 2048 before the $93 \%$ is achieved.

In summary, I believe the U.S. \$12.8 trillion dollar economy will suffer a decrease with a possible heavy recession during this transition. What we need is for the Government to take a strong lead, like the European Governments in this transition. In any event, the Solar-Hydrogen Economy is the greatest financial opportunity in our history. The past computer growth will pale by comparison.

\section{BIBLIOGRAPHY}

1. W. D. Reynolds, "Why we need the solar-hydrogen economy now" see: www.hydrogennow.org "The next step: conversion to the solar-hydrogen economy" Parts I and II see www.energypulse.net

2. World Council for Renewable Energy: World renewable energy agenda

3. Solar Energy Technologies Program: Solar FAQs see: www.eere.energy.gov

4. A. J. Nozik, PhysChem Paper \#87, ACS National meeting March 2007 Chicago

5. J. Johnson, "Farm Energy", see www.cen-online.org

6. A. McKillop, "Peak oil to peak gas is a short ride", www.energypulse.net

7. M.D. Savinor, "Life after the oil crash" see www.lifeaftertheoilcrash.net rev. 4/07

8. L. de Sousa, "Natural gas: how big is the problem ?" and "How to address contrarian arguments - part II" see www.theoildrum.com

9. M. Kanellos, "Full steam ahead for Nevada solar project" C|net News see: http://news.com.com

10. Photos, Nevada solar project courtesy of C/net News see: http://i.n.com.com

11. PESWIKI "Directory: cents per kilowatt-hour" http://peswiki.com

12 S. Cox "Goodbye to all that oil" see www.alternet.org

13. R. C. Duncan and W. Youngquist "The world petroleum life-cycle" see http://dieoff.org

14. Chapter 1. "World energy and economic outlook" see: www.eia.doe.gov

15. K. Kohl, "Is oil's ride almost over ?" see www.energyandcapital.com

16. Exxon Mobil Corp. "The outlook for energy - a view to 2030" see www.exxonmobile.com

17. Email to W. D. Reynolds from Albert Opdenaker, Asst. Dir., Office of Science, DOE 29 November 2006 on nuclear fusion budget.

18. J. Bell, "Nuclear power - one of humankind's biggest mistakes" see: www.energypulse.net 17 November 2006

19. W. D. Reynolds: Compressed air calculations, see also: The concept of PV work in chemistry http://dbhs.wvusd.k12.ca.us section on Thermochemistry.

20. "Terrestrial solar cell surpasses $40 \%$ efficiency" see www.gizmag.com

21. V. Garboushian "'World record efficiency" see. http://72.14.235.104 and www.solar.unlv.edu 
22. "Cost of PV concentrators falling fast" see: www.terradaily.com

23. Dr. Hubbert's general curve see: http://en.wikipedia.org figure 20.

24. "US Oil Production and Imports 1920-2005" see: see: http://en.wikipedia.org

25. "Image: Norway Hubbert" see: http://en.wikipedia.org

26. "Image: Hubbert World 2004" see: http://en.wikipedia.org

27. Middle east annual production 1960-2040 see: $\mathrm{http} / / /$ dieoff.org Page 133

28. World's annual liquids production 1900-2100 see: www.oildrum.com J. Laherrere'

29. A. B. Lovins "Twenty Hydrogen Myths" Rocky Mountain Institute 17 Feb 2005 update see: www.rmi.org

30. "Energy Innovations: A prosperous path to a clean environment" see: www.environmentalexpert.com ; G. Dauncy "Getting back on track: can we phase out fossil fuels by 2025" Climates of Change Congress, Canada 2000 and updates.

31. NREL report "Hydrogen Economy: Opportunities, Costs, Barriers and R\&D Needs" M. Rampage, Chair, 2004 and Calif. Energy Commission report :Distributed Energy Resource" Jan 2002 and updated see: www.energy.ca.gov

32. W. D. Reynolds cost calculations and updates from ref. 31.

33. S. Brooks "New bladeless design for turbines could dramatically lower the cost of energy production" see:www.iaus.com/turbine

34. D. Karmann "World's largest solar power plant" see: http://news.com.com

35. Pacific Power cost table summary for various electric generators Oct. 2006

36. Stirling Energy Systems see: www.stirlingenergy.com also email to W. D. Reynolds:ses@stirlingenergy.com

37. S. W. White, et.al., "Life cycle energy cost of wind and gas-turbine power" see: www.neep.wisc.edu/FTI and calculations

38. D. Lakey “130 MW gas turbine combined cycle power plant” SP Newsprint Co. and K. Darrow, Energy and Environmental Analysis, Inc. Bellevue, WA

39. "Full solar spectrum nitrides" see: www.lbl.gov/science-articles/archive

40. " 6 cents per $\mathrm{kWh}$ : world's largest solar project unveiled" see: http://i.treehugger.com.files

41. "Chapter Two: Fundamentals" wind power see: www.ece.unb.ca

42. "Estimating output" windpower see: www.solareco.com

43. California PUC approves Stirling Energy System's solar energy contract with Southern California Edison see: www.stirlingenergy.com

44. CHP fuel cell costs see: www.energy.ca.gov and NREL report 2004 "Hydrogen Economy"

45. "A boost for hydrogen fuel cell research" 26 Jan 2007 see: www.sciencedaily.com

46. "EU posts drop in greenhouse gas" see: www.cen-online.org

47. "Hydrogen safety - The Hindenburg accident" see: www.humboldt.edu Schatz Energy Research Center

48. J. I. Levene "Economic analysis of hydrogen production from wind" presented at the Windpower Conference, 15-18 May, 2005, Denver; see: www.osti.gov

49. W. Walukiewicz, et.al., "Effects of the narrow band gap on the properties on InN" J. Physical Review B, 15 Nov 2002; see also: www.lbl.gov/Science-Articles/Archive

50. Email to W.D. Reynolds from V. Garboushian, Amonix Corp. 5 Mar 2007 on costs of PV arrays and land area.

51. "Lessons learned from the U.S. PV industry" report NREL/PR-500-40099; Presented at AWEA Windpower Conf. 4-7 June 2006.

52. "New world record in wind power capacity in 2006" 29 Jan 2007 see: www.windea.org

53. G. W. Crabtree and N. S. Lewis "Solar energy conversion" Physics Today 60(3)37-42 Mar. 2007 see: www.aip.org

54. See: www.solarbuzz.com March 2007 and later issues

55. Stirling energy systems signs second largest solar deal in California" see: www.stirlingenergy.com 
56. "Chevron Energy completes solar project for US Postal Service" see: www.fnlink.com

57. "Google plans largest US solar-powered office" see: www.planetark.com

58. "Governor Bush breaks ground on Florida's "hydrogen highway" see: www.chevron.com

59. "Wind energy projects throughout the U.S.A." www.awea.org/projects

60. "AQMD celebrates grand opening of first "hydrogen highway" network" see: $\underline{w w w . a q m d . g o v / n e w s l}$

61. "Next generation fuel cell system propels GM's Sequel" see: $\underline{\text { www.evworld.com }}$

62. "The future of transportation" see: www.forbesautos.com/news

63. "Fuel-cell fleet : Ford producing hydrogen-powered V10 for use in shuttle busses" see: www.autonews.com; www.media.ford.com; http://thefraserdomain.typepad.com

64. "Solar power breakthrough: IAUS hits milestone previously thought to be impossible" see: www.electricnet.com

65. M.S. Ryan and J.-P. Fleurial "Thermal to electric power conversion using thermoelectric microconverters" see: The Electrochemical Society Interface, summer 2002

66. "RPS caps Japan wind growth" see: www.emerging-energy.com

67. "Betz Law" see: www.windpower.org

68. "China makes huge breakthrough in wind power technology" see: www.worldwatch.org

69. "Energy recovery turbine" see: www.centripetal-dynamics.com

70. "Workshop in electrolysis production of hydrogen from wind and hydro power" Proceedings www1.eere.energy.gov/hydrogenandfuelcells/wkshop_wind_hydro.html

71. L. Fingersh, M. Hand and A. Laxson "Wind turbine design cost and scaling model" Technical report NREL/TP-500-40566 Dec. 2006

72. "The economics of wind energy" Feb 2005 see: www.awea.org

73. "China aims to clean up in solar power" 11 April 2007 see: www.businessweek.com

74. Speech by China's Z. Guobao, Deputy Director of National Development and Reform Commission at the International Renewable Energy Conference, 7 Nov 2005

75. Z. Li "Solar energy booming in China" 23 Sep 2005 see: www.worldwatch.org

76. "What will happen next" page 2-3 see: www.solarplaza.com

77. "Japanese solar market to grow 30-40\% a year until FY 2008" 12 April 2006 see: http://climatechangenews.blogspot.com

78. "Hydrogen on the road" see: www.h2euro.org

79. “Japanese PV market - solar energy" May 2005 see: www.solarbuzz.com/fastfactsjapan

80. "Solar energy solutions group" pgs3-5 see: http://74.14.253.104

81. "Honda entering solar cell market for homes and vehicles" see: $\underline{w w w . g r e e n c a r c o n g r e s s . c o m}$

82. "European market for wind turbines grows 23\% in 2006" 1 Feb 2007 see: www.ewea.org

83. "Global wind energy markets continue to boom - 2006 another record year" see: www.gwec.net

84. "The world's leader in wind power" see: www.scandinavica.com/culture/wind.htm

85. "Developers look to unlock Poland wind potential" see: www.energyin-energy.com

86. "Mega contracts tighten W.G. competition in Spain" see: www.energying-energy.com

87. "Solar energy sales projects/green power - USA - 3 months summary" see: www.solarbuzz.com

88. "Hyfleet:cute FAQs" see: www.global-hydrogen-bus-platform.com

89. Tech corner- Hydrogen bus source "Berlin to launch Hyfleet HICE bus fleet to follow CUTE program" see www.weststart.org

90. "Sunline transit agency" see: http://72.14.253.104

91. "Fuel cell bus passes 5,000 hours of operation" 2 Jan 2007 see: www.global-hydrogen-bus-platform.com

92. "Phase one of 40 MW German solar park begun" 23 Jan 2007 see: www.renewableaccessenergy.com 
93. "More on German green energy" see: www.worldchanging.com

94. "Iceland hots up towards hydrogen" The Fuel Cell Review, June/July 2006

95. "The hydrogen train: feasibility study 2005-2006" see: www.hydrogentrain.eu

96. "Scandianian hydrogen highway partnership formed" 26 June 2006 see: www.h2euro.org

97. J.Glowicki "Industry insider: dropping the fossil-fuel habit" 7 Sept 2005 see: http://consumerguideauto.howstuffworks.com/articles

98. "Renewable energy: Commission calls for a stronger commitment of member states to achieve the 2010 targets" 26 May 2004 see: http://europa.eu/rapid

99. "2007 world PV industry report highlights" 19 Mar 2007 see: http://register.solarbuzz.com

100. "US grid connect PV market report 2006" 19 June 2006 see: http://register.solarbuzz.com 
Downloaded From: https://www.spiedigitallibrary.org/conference-proceedings-of-spie on 26 Apr 2023

Terms of Use: https://www.spiedigitallibrary.org/terms-of-use 


\title{
Solar Hydrogen Production by Tandem Cell System Composed of Metal Oxide Semiconductor Film Photoelectrode and Dye-Sensitized Solar Cell
}

\author{
H. Arakawa, C. Shiraishi, M. Tatemoto, H. Kishida, D. Usui, A. Suma, A. Takamisawa \\ and T. Yamaguchi \\ Tokyo University of Science, 12-1 Ichigaya-Funagawara, Shinjuku, Tokyo, 162-0826, Japan
}

\begin{abstract}
Photocatalytic and photoelectrochemical approaches to solar hydrogen production in our group were introduced. In photocatalytic water splitting system using $\mathrm{NiO}_{\mathrm{x}} / \mathrm{TiO}_{2}$ powder photocatalyst with concentrated $\mathrm{Na}_{2} \mathrm{CO}_{3}$ aqueous solution, solar energy conversion efficiency to $\mathrm{H}_{2}$ and $\mathrm{O}_{2}$ production (STH efficiency) was $0.016 \%$. In addition, STH efficiency of visible light responding photocatalyst, $\mathrm{NiO}_{\mathrm{x}} /$ promoted $\mathrm{In}_{0.9} \mathrm{Ni}_{0.1} \mathrm{TaO}_{4}$, was estimated at $0.03 \%$. In photoelectrochemical system using an oxide semiconductor film phptoelectrode, $\mathrm{STH}$ efficiencies of meosporous $\mathrm{TiO}_{2}$ (Anatase), mesoporous visible light responding S-doped $\mathrm{TiO}_{2}$ (Anatase) and $\mathrm{WO}_{3}$ film were $0.32-0.44 \%$ at applied potential of $0.35 \mathrm{~V}$ vs NHE, $0.14 \%$ at $0.55 \mathrm{~V}$ and $0.44 \%$ at $0.9 \mathrm{~V}$, respectively. Finally, solar hydrogen production by tandem cell system composed of an oxide semiconductor photoelectrode, a Pt wire counter electrode and a dye-sensitized solar cell (DSC) was investigated. As photoelectrodes, meosporous $\mathrm{TiO}_{2}$ (Anatase), mesoporous S-doped $\mathrm{TiO}_{2}$ (Anatase), $\mathrm{WO}_{3}, \mathrm{BiVO}_{4}$ and $\mathrm{Fe}_{2} \mathrm{O}_{3}$ film were tested. STH efficiency of tandem cell system composed of a $\mathrm{WO}_{3}$ film photoelectrode, and a two-seriesconnected DSC $(\mathrm{Voc}=1.4 \mathrm{~V})$ was $2.5-2.8 \%$. In conclusion, it is speculated that more than $5 \% \mathrm{STH}$ efficiency will be obtained by tandem cell system composed of an oxide semiconductor photoelectrode and a two-series-connected DSC in near future. This suggests a cost-effective and practical application of this system for solar hydrogen production.
\end{abstract}

Keywords: Solar hydrogen production, Tandem cell system, Mesoporous oxide semiconductor film photoelectrode, $\mathrm{TiO}_{2}$, S-doped $\mathrm{TiO}_{2}, \mathrm{WO}_{3}, \mathrm{BiVO}_{4}, \mathrm{Fe}_{2} \mathrm{O}_{3}$, Dye-sensitized solar cell,

\section{INTRODUCTION}

As one of countermeasures against global warming issue, development of new cost-effective technologies utilizing renewable energy is strongly requested. Solar light energy, which is inexhaustible and free energy, might be a main target to be utilized. In addition to photovoltaic cell system, solar hydrogen production is very attractive way to harvest and store solar energy. It is well known that a combination process of photovoltaic cell and water electrolysis is a practical way to solar hydrogen production. However, solar cell system is still expensive for solar hydrogen production. It is requested to develop a cost-effective process. Direct water splitting into $\mathrm{H}_{2}$ and $\mathrm{O}_{2}$ using oxide semiconductor powder photocatalyst is one of the alternatives. This system is relatively costless and robust. However, STH efficiency is quite low at present. Therefore, we need to develop new materials which can utilize abundant visible light effectively for water splitting. In addition to new materials for effective light harvest, suppression of unwanted reactions, such as backward reaction of water splitting over photocatalyst and charge recombination reaction between excited electrons on the conduction band and positive charge holes on valence band of semiconductor, are subjects for improving efficiency. The other alternative way is photoelectrochemical water splitting system composed of an oxide semiconductor photoelectrode and a metal counter electrode. This system can suppress not only charge recombination process but also back ward reaction by applying potential. Therefore it might result in an increase of efficiency. However, we need electricity for applied potential. This is a weak point of photoelectrochemical approach of solar hydrogen production. In order to compensating this weak point of photoelectrochemical system, a tandem cell system composed of an oxide semiconductor film photoelectrode and a dye-sensitized solar cell (DSC) was proposed by Augustynski and Graetzel. ${ }^{1)}$ This system might be relatively cost-effective process because DSC is recognized cheaper one third to one fifth than silicon solar cell. In this presentation, our approach to solar hydrogen production is introduced.

*h.arakawa@ci.kagu.tus.ac.jp; phone+91-3-5228-8311; fax +81-3-3235-2214 


\section{SOLAR HYDROGEN PRODUCTION BY OXIDE SEMICONDUCTOR POWDER PHOTOCATALYSTS}

Since photoelectrochemical water splitting into $\mathrm{H}_{2}$ and $\mathrm{O}_{2}$ using a $\mathrm{TiO}_{2}$ (Rutile) single crystal photoelectrode and a Pt counter electrode was reported by Honda and Fujishima in 1972, extensive studies in photocatalytic water splitting using a metal promoted oxide semiconductor powders such as $\mathrm{Pt} / \mathrm{TiO}_{2}$ (Anatase) have been reported so far. Figue 1 shows conceptual mechanisms of photocatalytic water splitting. The one is for one-step water splitting using one powder photocatalyst composed of metal promoted oxide semiconductor. The other is for two-step water splitting using two different powder photocatalysts composed of metal promoted semiconductors for $\mathrm{H}_{2}$ and $\mathrm{O}_{2}$ evolution, respectively. In this system, a redox mediator such as $\mathrm{Fe}^{3+} / \mathrm{Fe}^{2+}$ is essential in order to carry electrons between two different photocatalysts. Two-step water splitting system is similar to The Z-scheme of natural photosynthetic process, which is a two-photon exciting system. Therefore, STH efficiency of this system might be lower than that of one-step water splitting system. However, this system has a merit for wide selection of photocatalysts for two half reactions of water splitting. A redox mediator is also able to be selected.

Principle of water splitting by solid photocatalyst

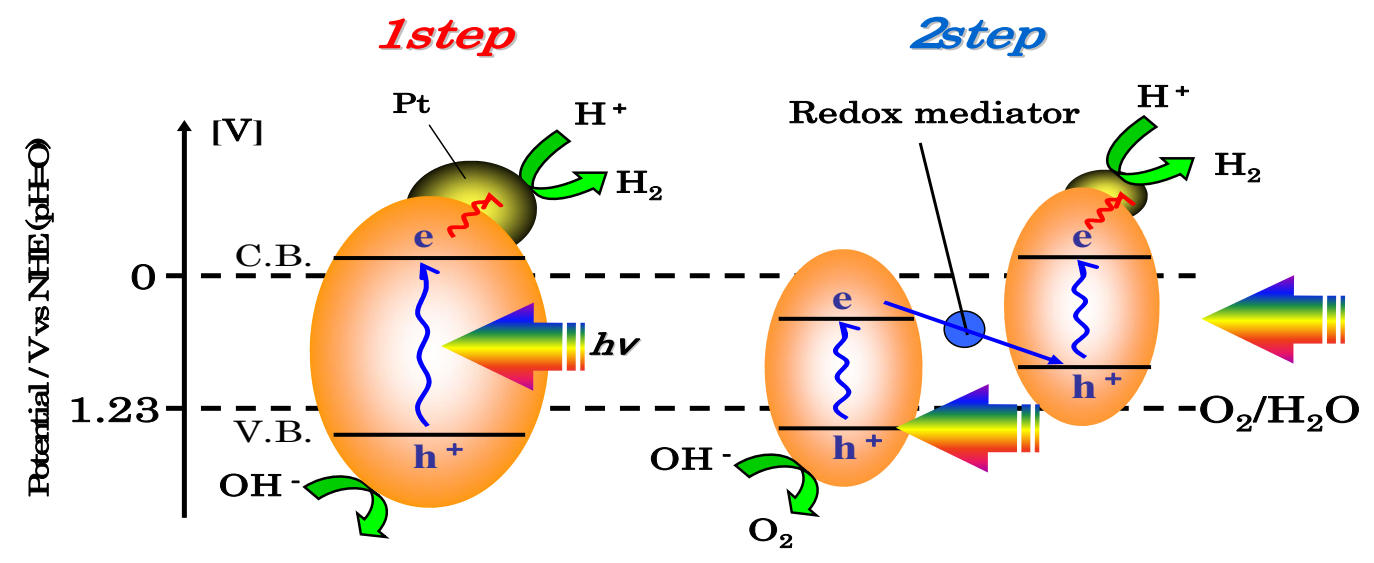

Fig. 1. Water splitting mechanisms using powder photocatalysts of metal promoted oxide semiconductor

\subsection{Solar hydrogen production using UV light responding oxide semiconductor photocatalysts}

So far, many powder photocatalysts of oxide semiconductors are reported for one-step water splitting. ${ }^{3)}$ However most of them are active under only UV light irradiation for a stoichiometric water splitting into $\mathrm{H}_{2}$ and $\mathrm{O}_{2}$. Figure 2 shows water splitting performance of typical powder photocatalysts of UV light responding under irradiation by full arc of 400W high-pressure $\mathrm{Hg}$ lamp. The most active photocatalyst among them was $\mathrm{NaTaO}_{3}$ photocatalyst $(\mathrm{B} . \mathrm{G} .=4.1 \mathrm{eV})$, which was active under irradiation of light shorter than $302 \mathrm{~nm}^{4}$ This photocatalyst produced both $\mathrm{H}_{2}$ of $448 \mathrm{ml}$ and $\mathrm{O}_{2}$ per of $220 \mathrm{ml}$ for one hour and per $0.5 \mathrm{~g}$-cat. Unfortunately, the light shorter than $302 \mathrm{~nm}$ does not include in AM1.5 solar light. Therefore we can not utilize this photocatalyst for solar hydrogen production. We found a significant promoting effect of aqueous $\mathrm{Na}_{2} \mathrm{CO}_{3}$ solution on stoichiometric water splitting over $\mathrm{Pt} / \mathrm{TiO}_{2}$ (Anatase) photocatalysst. ${ }^{5}$ Hydrogen of $85 \mathrm{ml}$ and $\mathrm{O}_{2}$ of $43 \mathrm{ml}$ were produced for one hour and per $0.5 \mathrm{~g}$ of $\mathrm{Pt} / \mathrm{TiO}_{2}$ photocatalyst under the same irradiation conditions. There are few reports, which describes STH efficiency of powder photocatalysts of oxide semiconductor. Therefore, we tested solar hydrogen production using an aqueous suspension of $\mathrm{Na}_{2} \mathrm{CO}_{3}$ and $\mathrm{NiO}_{\mathrm{x}} / \mathrm{TiO}_{2}$ (Anatase) powder photocatalyst. Under 6-hour irradiation of natural solar light in July at Tsukuba, Japan, $\mathrm{H}_{2}$ of $400 \mathrm{ml} / \mathrm{m}^{2}$ and $\mathrm{O}_{2}$ of $200 \mathrm{ml} / \mathrm{m}^{2}$ were produced. STH efficiency of this experiment was only $0.016 \%{ }^{6}{ }^{6}$ 


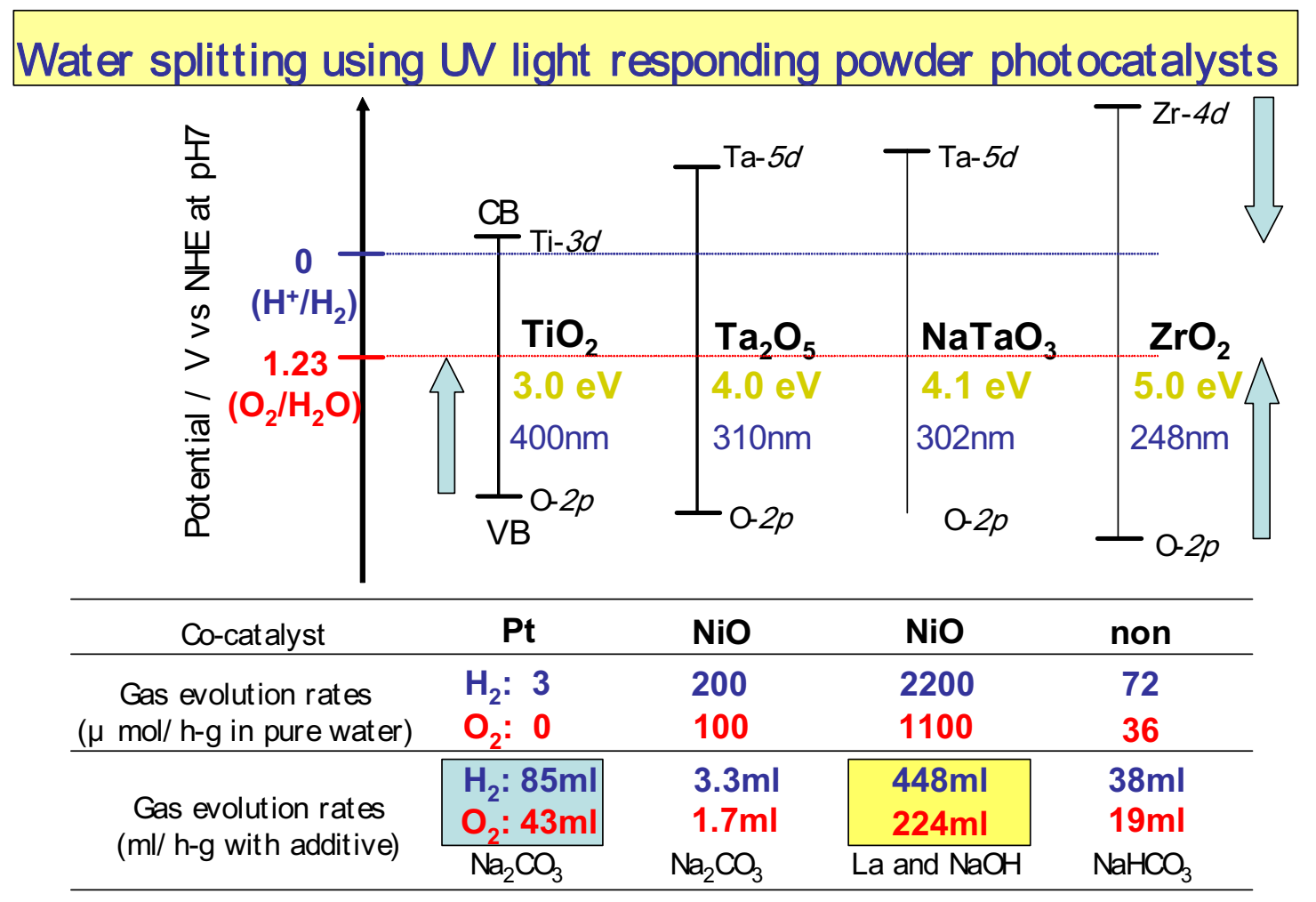

$400 \mathrm{~W}$ - High pressure Hg lamp equipped with quartz water jacket $(\lambda>200 \mathrm{~nm}), \mathrm{H}_{2} \mathrm{O}: 400 \mathrm{ml}$

Fig. 2. Stoichiometric water splitting using typical UV light responding powder photocatalysts

\subsection{Solar hydrogen production using visible light responding oxide semiconductor photocatalysts}

In order to improve water splitting efficiency of photocatalysts, it is very important to develop visible light responding photocatalysts. One of approaches to realize visible light responding photocatalysts is a doping of wide band gap semiconductors. Typical examples are $\mathrm{N}$-doped $\mathrm{TiO}_{2}$ (Anatase) ${ }^{7)}$ and $\mathrm{S}$-doped $\mathrm{TiO}_{2}$ (Anatase). ${ }^{17)}$ These photocatalysts are active for decomposition of organic compounds and organic contaminants. However, water splitting ability of these compounds is quite low even compared with those of non-doped $\mathrm{TiO}_{2}$ (Anatase) photocatalysts. Chargerecombination process might be accelerated by the presence of doping level. The other approach is to develop and find new materials for visible light responding. We have screened various kinds of mixed oxide semiconductor materials. As a result, we found $\mathrm{InTaO}_{4}$ and $\mathrm{InNbO}_{4}$ could split water under visible light irradiation. ${ }^{8,9)}$ Furthermore, water splitting activity increased 4 times higher by $\mathrm{NiO}_{\mathrm{x}} / \mathrm{In}_{0.9} \mathrm{Ni}_{0.1} \mathrm{TaO}_{4}$ photocatalyst. ${ }^{10)}$ Hydrogen and oxygen were produced with the rate of $0.672 \mathrm{ml} / \mathrm{h} \cdot \mathrm{g}$-cat and $0.336 \mathrm{ml} / \mathrm{h} \cdot \mathrm{g}$-cat, respectively, under visible light irradiation $(\lambda>420 \mathrm{~nm}, 300 \mathrm{~W}$-Xe lamp). Water splitting lasted steadily for more than $400 \mathrm{hrs}$ under visible light irradiation. The estimated STH efficiency of this powder photocatalyst was $0.03 \%$. Recently, new oxy-nitride photocatalysts such as $\mathrm{ZnO}: \mathrm{GaN}$ were reported for visible light water splitting by Domen et al. ${ }^{11)}$ We speculate STH efficiency of this photocatalyst is below $0.1 \%$.

\subsection{Solar hydrogen production using a two-step water splitting system}

Screening of photocatalysts was conducted for a two-step water splitting system under visible light irradiation. As a result, the combination of $\mathrm{Pt} / \mathrm{WO}_{3}$ photocatalyst for $\mathrm{O}_{2}$ evolution, $\mathrm{Pt} / \mathrm{Cr}$,Ta-co-doped $\mathrm{SrTiO}_{3}$ photcatalyst for $\mathrm{H}_{2}$ evolution and $\mathrm{I}^{-} / \mathrm{IO}_{3}{ }^{-}$redox mediator has proved to be active for visible light water splitting. ${ }^{12)}$ This system is the first 
example of a two-step visible light water splitting system. The gas evolution rates of $\mathrm{H}_{2}$ and $\mathrm{O}_{2}$ were $0.179 \mathrm{ml} / \mathrm{h} \cdot \mathrm{g}$-cat. and $0.089 \mathrm{ml} / \mathrm{h} \cdot \mathrm{g}$-cat, respectively. The estimated STH efficiency of this photocatalyst system is only $0.005 \%$.

\section{SOLAR HYDROGEN PRODUCTION BY PHOTOELECTROCHEMICAL CELLS COMPOSED OF OXIDE SEMICONDUCTOR PHOTOELECTRODE AND PT WIRE COUNDER ELECTRODE}

Photocatalytic water splitting system is very simple and cost-effective. However, as we see, STH efficiencies of this system is very low at this moment. The reason for low efficiency is ascribed to have unwanted reactions such as backward reaction of water splitting, water formation, and charge recombination reaction between photoexcited electrons on the conduction band and positive charge holes on valence band of semiconductor. In a photelectrochemical cell, both unwanted reactions might be suppressed by applied potential as well as separation of gas evolution by two different electrodes. Therefore, efficiency of water splitting is speculated to be improved, though this system is relatively expensive compared with photocatalyst system.

Figure 3 shows a photoelectrochemical cell set up for water splitting. Transparent, thin and/or mesoporous oxide semiconductor film photoelectrodes were prepared onto FTO conducting glass by screen print, spin coat and Doctor-blade methods. Transparent film

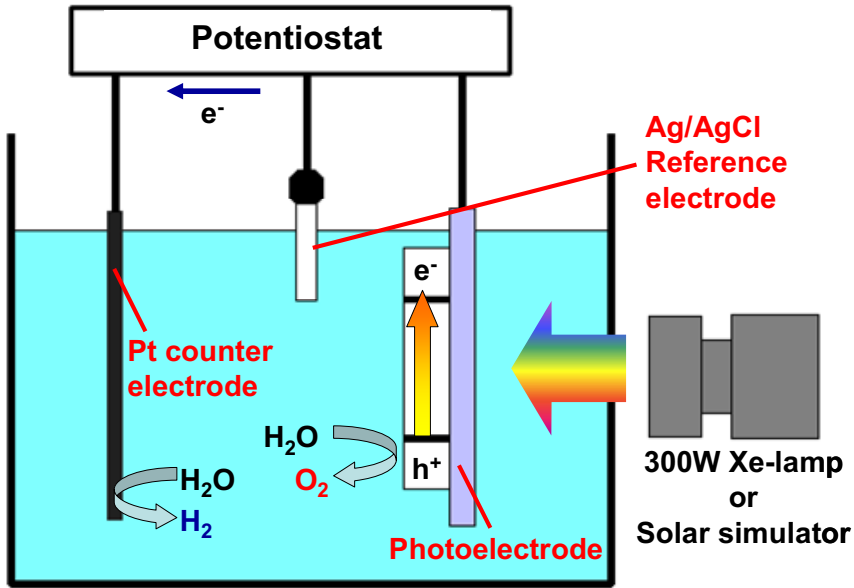

Fig. 3. Photoelectrochemical cell set up

Three-electrode cell (W.E.= photoelectrode, C.E. $=$ Pt wire, R.E. $=\mathrm{Ag} / \mathrm{AgCl})$. Irradiation source $=$ Solar simulator $\left(\right.$ AM1.5, $100 \mathrm{mw} / \mathrm{cm}^{2}$, is also used by a tandem cell system. Recently, transparent oxide semiconductor photoelectrodes receive much attention in terms of efficient water splitting. For example, a high photocurrent of water splitting over transparent $\mathrm{WO}_{3}$ and $\mathrm{Fe}_{2} \mathrm{O}_{3}$ photoelectrodes under simulated solar light was reported by Augustynski ${ }^{13)}$ and Graetzel ${ }^{14)}$ et al.

\subsection{Solar hydrogen production using mesoporpous $\mathrm{TiO}_{2}$ (Anatase) photoelectrode}

First of all, we decided to fabricate $\mathrm{TiO}_{2}$ (Anatase) film photoelectrode, because $\mathrm{TiO}_{2}$ photoelectrode is well known as an active water splitting photoelectrode. ${ }^{2)}$ We would like to know how efficiently $\mathrm{TiO}_{2}$ thin film photoelectrode could split water compared with $\mathrm{TiO}_{2}$ powder photocatalyst. We prepared mesoporous $\mathrm{TiO}_{2}$ film photoelectrode. It is speculated that mesoporous thin film photoelectrode has a larger surface area than that of non-porous sintered or single crystal photoelectrode. Therefore, interface area between electrolyte solution and photoelectrode surface might be much increased, resulting a higher efficiency. $\mathrm{TiO}_{2}$ photoelectrode was fabricated by screen printing of $\mathrm{TiO}_{2}$ paste onto FTO conducting glass, followed by drying and then calcination at $\left.600-700^{\circ} \mathrm{C} .{ }^{15}\right) \mathrm{TiO}_{2}$ paste was composed of $\mathrm{TiO}_{2}$ nanocrystal particles of $20 \mathrm{~nm}$ in diameter, organic binder and ethanol solvent. Optimum thickness of $\mathrm{TiO}_{2}$ film was 3-10 $\mu$. The size of $\mathrm{TiO}_{2}$ photoelectrode was a $1 \mathrm{~cm}-$ by- $1 \mathrm{~cm}$. As an electrolyte solution, $\mathrm{NaOH}$ aqueous solution was used. Concentration of $\mathrm{NaOH}$ was changed from $0.1 \mathrm{M}$ to $1.0 \mathrm{M}$. $\mathrm{TiO}_{2}$ photoelectrode, $\mathrm{Pt}$ wire counter electrode and $\mathrm{Ag} / \mathrm{AgCl}$ reference electrode were connected to the potentiostat. Water splitting ability of oxide semiconductor photoelectrde was estimated by measuring photocurrent under irradiation. A very good relationship between measured photocurrent and produced amount of $\mathrm{H}_{2}$ was obtained. Hydrogen of $0.008 \mathrm{ml}$ was produced by $1 \mathrm{~mA}$ current flow for one minute. Under irradiation by a solar simulator (AM1.5, 100mw/ $/ \mathrm{cm}^{2}$, one sun), an I-V curve was measured. Steady photocurrent of 0.4$0.6 \mathrm{~mA} / \mathrm{cm}^{2}$ was obtained. Then STH efficiency was calculated from the following equation (1), 


$$
\eta(\%)=\frac{J(1.23-E)}{I} x 100
$$

where $\eta(\%)$ is solar energy conversion efficiency (STH efficiency) in $\% . J$ denotes produced photocurrent in $\mathrm{mA} / \mathrm{cm}^{2}$ at $E$. $E$ denotes applied potential in voltage. $I$ denotes solar irradiance, that is, one sun, $100 \mathrm{~mW} / \mathrm{cm}^{2}$, AM1.5. Calculated STH efficiency changed with applied potential. The maximum STH efficiency was $0.32-0.44 \%$ at $0.35 \mathrm{~V}$ vs NHE for mesoporous $\mathrm{TiO}_{2}$ photoelectrode.

\subsection{Solar hydrogen production using mesoporpous visible light responding $\mathrm{S}-d o p e d ~ \mathrm{TiO}_{2}$ (Anatase) photoelectrode}

Recently, various kinds of visible light responding doped $\mathrm{TiO}_{2}$ materials, such as nitrogen doped $\mathrm{TiO}_{2}(\mathrm{~N}$-doped $\left.\mathrm{TiO}_{2}\right)$, ${ }^{7}$ carbon doped $\mathrm{TiO}_{2}\left(\mathrm{C} \text {-doped } \mathrm{TiO}_{2}\right)^{16)}$ and sulfur doped $\mathrm{TiO}_{2}\left(\mathrm{~S}\right.$-doped $\left.\mathrm{TiO}_{2}\right),{ }^{17)}$ are reported and their photocatalytic performance for organic contaminants decomposition are studied. Therefore, we investigated photoelectrochemical water splitting using visible light responding $\mathrm{S}$-doped $\mathrm{TiO}_{2}$ photoelectrode. ${ }^{15}$ ) S-doped $\mathrm{TiO}_{2}$ powder was prepared from Titanium (IV) iso-propoxide $\left(\mathrm{Ti}\left(\mathrm{OC}_{3} \mathrm{H}_{7} \mathrm{O}\right)_{4}\right)$ and Thiourea $\left(\mathrm{H}_{2} \mathrm{NC}=\mathrm{SNH}_{2}\right)$. Ethanol mixture of two compounds was well mixed and then dried. White residue was calcined at $500^{\circ} \mathrm{C}$ for 3 hours. Crystallographic structure of prepared S-doped $\mathrm{TiO}_{2}$ powder was Anatase phase. Light absorption edge of this powder expanded broadly up to $500 \mathrm{~nm}$. A paste preparation and screen printing process was the same as that of non-doped $\mathrm{TiO}_{2}$ photoelectrode. Sdoped $\mathrm{TiO}_{2}$ photoelctrode was calcined at $500^{\circ} \mathrm{C}$. Photocurrents of $0.2 \mathrm{~mA} / \mathrm{cm}^{2}$ and $0.3 \mathrm{~mA} / \mathrm{cm}^{2}$ were obtained at applied potential of $0.5 \mathrm{~V}$ and $1.5 \mathrm{~V}$ vs NHE, respectively, under irradiation by solar simulator. Maximum STH efficiency was $0.12-0.14 \%$ at applied potential of $0.55 \mathrm{~V}$ vs NHE. STH efficiency of S-doped $\mathrm{TiO}_{2}$ photoelectrode was lower than that of non-doped $\mathrm{TiO} 2$ photoelectrode though light absorption area is fairly wider than that of non-doped $\mathrm{TiO}_{2}$ photoelectrode. Sulfur doping $\mathrm{n}$ band gap might accelerate charge recombination process.

\subsection{Solar hydrogen production using a mesoporous $\mathrm{WO}_{3}$ photoelectrode}

$\mathrm{WO}_{3}$ powder photocatalyst can split water efficiently and produce $\mathrm{O}_{2}$ evolution in the presence of sacrificial reagent such as $\mathrm{AgNO}_{3}$ aqueous solution under visible light irradiation. Light absorption edge of $\mathrm{WO}_{3}$ is about $470 \mathrm{~nm}$. Therefore, $\mathrm{WO}_{3}$ is one of attractive materials for $\mathrm{O} 2$ evolution photoelectrode. Augustynski and co-workers have extensively investigated $\mathrm{WO}_{3}$ photoelectrodes for water splitting ${ }^{13,18,19,20)}$ and they obtained relatively higher photocurrent such as $3.5 \mathrm{~mA} / \mathrm{cm}^{2}$. We also investigated water splitting using $\mathrm{WO}_{3}$ photoelectrode. Our $\mathrm{WO}_{3}$ paste was composed of $\mathrm{H}_{2} \mathrm{WO}_{4}, \mathrm{PEG} 300$, hydroxypropylcellulose and small amount of ethanol solvent. $\mathrm{WO}_{3}$ paste was coated onto FTO glass by Doctor-blade method and calcined at $500^{\circ} \mathrm{C}$ for one hour. This process was repeated for increasing film thickness to obtain the maximum photocurrent. A steady state photocurrent of $2.25 \mathrm{~mA} / \mathrm{cm}^{2}$ was obtained in $0.1 \mathrm{~N}-\mathrm{H}_{2} \mathrm{SO}_{4}$ solution under solar simulated light. STH efficiency of our system was $0.44 \%$ at applied potential of $0.9 \mathrm{~V}$ vs NHE.

Recently Miller and co-workerl reported a higher photocurrent such as $3.5 \mathrm{~mA} / \mathrm{cm}^{2}$ using $\mathrm{WO}_{3}$ photoelectrode prepared by low temperature reactive sputtered process. ${ }^{21)}$

\subsection{Solar hydrogen production using $\mathrm{BiVO}_{4}$ and $\mathrm{Fe}_{2} \mathrm{O}_{3}$ photoelectrodes}

It is reported that $\mathrm{BiVO}_{4}$ powder photocatalyst can also split water to $\mathrm{O}_{2}$ evolution in the presence of sacrificial reagent such as $\mathrm{AgNO}_{3}$ aqueous solution under visible light irradiation. ${ }^{22)}$ Light absorption edge of $\mathrm{BiVO}_{4}$ is about 550 $\mathrm{nm}$. Sayama and co-worker reported STH efficiency of $\mathrm{BiVO}_{4}$ photoelectrode system. ${ }^{23)}$ It was $0.2 \%$ under 2.6 sun. We prepared $\mathrm{BiVO}_{4}$ film photoelectrode by spin coating of concentrated precursor solution. A precursor solution of $\mathrm{BiVO}_{4}$ was produced by polymerized complex method using $\mathrm{BiNO}_{3} \cdot 5 \mathrm{H}_{2} \mathrm{O}$ and $\mathrm{NH}_{4} \mathrm{VO}_{3}$. At applied potential of $1.5 \mathrm{~V}, 0.7$ $\mathrm{mA} / \mathrm{cm}^{2}$ of photocurrent was obtained under one sun irradiation. STH efficiency of $\mathrm{BiVO}_{4}$ photoelectrode was $0.08 \%$ at applied potential of $0.95 \mathrm{~V}$.

Recently, $\mathrm{Fe}_{2} \mathrm{O}_{3}$ photoelectrode for water splitting has been becoming popular. Because a high photocurrent over $2 \mathrm{~mA} / \mathrm{cm}^{2}$ was reported by Graetzel and co-workers. ${ }^{24)}$ We prepared $\mathrm{Fe}_{2} \mathrm{O}_{3}$ photoelectrode film by spin coating of solution including $\mathrm{FeCl}_{3} \cdot 6 \mathrm{H}_{2} \mathrm{O}$ and organic binder in ethanol solvent. Spin coated $\mathrm{Fe}_{2} \mathrm{O}_{3}$ film on FTO glass was dried and then 
calcined at $500^{\circ} \mathrm{C}$ for 1 hour. Obtained photocurrent was $0.4 \mathrm{~mA} / \mathrm{cm}^{2}$ at applied potential of $1.5 \mathrm{~V}$ vs NHE and STH efficiency was $0.0023 \%$ at applied potential of $1.0 \mathrm{~V}$.

\section{FABRICATION OF EFFICIENT DYE-SENSITIZED SOLAR CELLS}

In solar hydrogen production using oxide semiconductor film electrodes, STH efficiency seems to be increased significantly under the applied potential at around $1.5 \mathrm{~V}$ vs NHE. Such applied potential might be supplied by DSC, which is one of candidates of cost-effective photoelectrochemical solar cell developed by Graetzel. ${ }^{25}$ Therefore, we have been trying to improve solar cell efficiency of DSC and to fabricate a DSC sub-module with high efficiency. Recently, we could obtain $10-11 \%$ efficiency in a small black dye sensitized $\mathrm{TiO}_{2}$ solar cell with a $5 \mathrm{~mm}$-by $5 \mathrm{~mm}$ size. ${ }^{26,27)}$. Furthermore, we could fabricate a $10 \mathrm{~cm}$-by- $10 \mathrm{~cm}$ DSC sub-module with efficiency of 8.4-9.0\%. ${ }^{28)}$ Fig. 4 shows such a sub-module of a black-dye-sensitized solar cell.

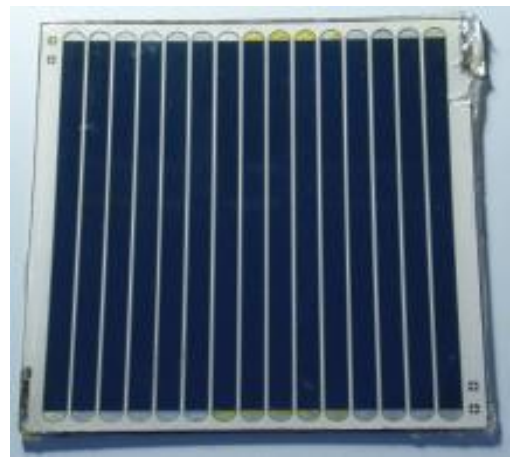

\section{Solar cell performance of a current collecting Black dye-sensitized $\mathrm{TiO}_{2}$ solar cell}

Cell size: $10 \mathrm{~cm}$ square

Active area of solar cell: $67.5 \mathrm{~cm}^{2}$

Aperture area: $81 \mathrm{~cm}^{2}$

Measuring condition: AM1.5, $100 \mathrm{~mW} / \mathrm{cm} 2$ (one sun)

Cell efficiency based on active area $\left(\eta_{\text {ac }}\right): 9.0 \%$

( Isc: $1.35 \mathrm{~A}$, Jsc: $20.0 \mathrm{~mA} / \mathrm{cm}^{2}$, Voc: $0.68, \mathrm{ff:} 0.66$ )

Cell efficiency based on aperture area $\left(\eta_{\text {aperture }}\right): 7.5 \%$

Fig.4. A 10cm-by-10cm sub-module of black-dye-sensitized solar cell and its solar cell performance

We fabricated tiny black-dye-sensitized solar cells for solar hydrogen production using a tandem cell system. The one is a single cell with a $1 \mathrm{~cm}-$ by- $1 \mathrm{~cm}$ size. A solar cell performance of single cell is $\eta_{\mathrm{ac}}=7.5 \%, \mathrm{Jsc}=20.1 \mathrm{~mA} / \mathrm{cm}^{2}$, $\mathrm{Voc}=0.68 \mathrm{~V}$ and $\mathrm{ff}=0.59$. The other is a two-series-connected cell with a $1 \mathrm{~cm}-$ by- $1 \mathrm{~cm}$ size. A solar cell performance of a two-series-connected cell is $\eta_{\mathrm{ac}}=6.1 \%, \mathrm{Jsc}=8.4 \mathrm{~mA} / \mathrm{cm}^{2}, \mathrm{Voc}=1.4 \mathrm{~V}$ and $\mathrm{ff}=0.52$. Fig. 5 . shows pictures of prepared cells.
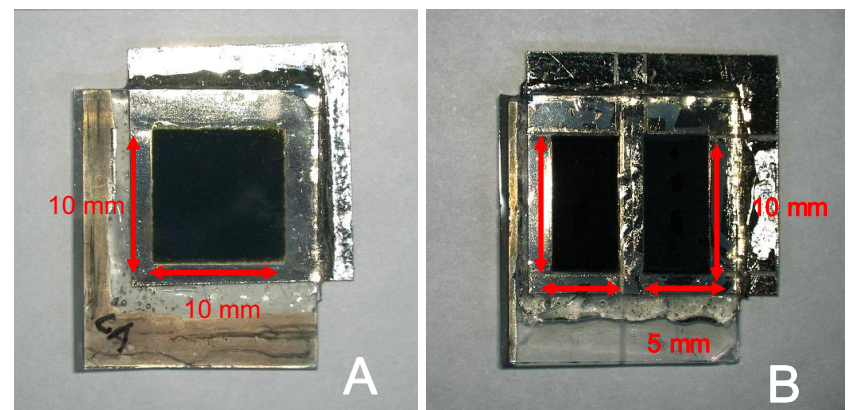

Picture A : a single with a $1 \mathrm{~cm}-$ by $-1 \mathrm{~cm}$ size

$(\eta=7.5 \% \mathrm{Jsc}=20.1 \mathrm{~mA} / \mathrm{cm} 2, \mathrm{Voc}=0.68 \mathrm{~V}, \mathrm{ff}=0.59)$

Picture B : a two-series-connected cell with a $1 \mathrm{~cm}-\mathrm{by}-1 \mathrm{~cm}$ size

$(\eta=6.1 \% \mathrm{Jsc}=8.4 \mathrm{~mA} / \mathrm{cm} 2, \mathrm{Voc}=1.39 \mathrm{~V}, \mathrm{ff}=0.52)$

Fig. 5. Pictures of tiny black-dye-sensitized solar cells for solar hydrogen production using a tandem cell system 


\section{SOLAR HYDROGEN PRODUCTION BY TANDEM CELL SYSTEM USING OXIDE SEMICONDUCTOR FILM AND DYE-SENSITIZED SOLAR CELL}

In order to improve STH efficiency of oxide semiconductor film photoelectrode, the tandem cell system was proposed by Swiss research group. ${ }^{1)}$ DSC supplies an additional potential up to about $1.5 \mathrm{~V}$ to oxide semiconductor film photoelectrode in order to obtain efficient water splitting into $\mathrm{H}_{2}$ and $\mathrm{O}_{2}$. This concept is shown in Figure 6. Photo-induced electron transfer mechanism of this concept is quite similar to the Zscheme of photosynthesis. Their tandem cell is composed of a thin and transparent film oxide semiconductor photoelectrode for $\mathrm{O}_{2}$ evolution, $\mathrm{Pt}$ wire counter electrode for $\mathrm{H}_{2}$ evolution and a dye-sensitized solar cell connected to both electroddes. .Figure 7 shows the structure of tandem cell system. In case of $\mathrm{TiO}_{2}$ photoelectrode, both $\mathrm{TiO}_{2}$ transparent thin film/FTO glass photoelectrode and Pt wire counter electrode were inserted into $0.1 \mathrm{M}-1.0 \mathrm{M}$ $\mathrm{NaOH}$ aqueous solution and they were connected each other through DSC.

Recently, Hydrogen Solar Ltd. in London announced that they developed the tandem cell system for water splitting with STH of 7\% efficiency. ${ }^{29)}$ This efficiency is significantly high, therefore it is very interesting to study tandem cell system in detail. First of all, we studied $\mathrm{TiO}_{2}$ system. Figure 8 shows I-V curves of three different systems under simulated solar light irradiation (AM1.5, $100 \mathrm{~mW} / \mathrm{cm}^{2}$, one sun).These I-V curves were measured using a two-electrode system in place of a three-electrode system using a $\mathrm{Ag} / \mathrm{AgCl}$ reference electrode. Red curve shows $\mathrm{I}-\mathrm{V}$ curve of mesoporous $\mathrm{TiO}_{2}$ photoelectrode composed of $\mathrm{TiO}_{2}$ particles with $20 \mathrm{~nm}$ in diameter, which was already described in section 3.1. Film thickness of this mesoporous $\mathrm{TiO}_{2}$ photoelectrode was $3 \mu$, which was thinner than that of mesoporous $\mathrm{TiO}_{2}$ photoelectrode used in section 3.1, that is, $10 \mu$ thickness. The onset of photocurrent of this system was $0.23 \mathrm{~V}$ vs counter electrode. To obtain a steady state photocurrent, $0.5 \mathrm{~mA} / \mathrm{cm}^{2}$, at least $0.5 \mathrm{~V}$ of applied potential is requested in this system. Blue curve shows I-V curve of a tandem cell composed of mesoporous $\mathrm{TiO}_{2}$ photoelectrode and a single cell of black-dye-sensitized solar cell (BDSC). The onset of photocurrent of this system shifted negatively about $0.7 \mathrm{~V}$, which is almost the same value of the photovoltage (Voc) of a single cell of BDSC, and it was $0.45 \mathrm{~V}$. It is clear that about $0.47 \mathrm{~mA} / \mathrm{cm}^{2}$ of photocurrent is able to be obtained without any applied potential in this system. Obtained photocurrent was slightly smaller than

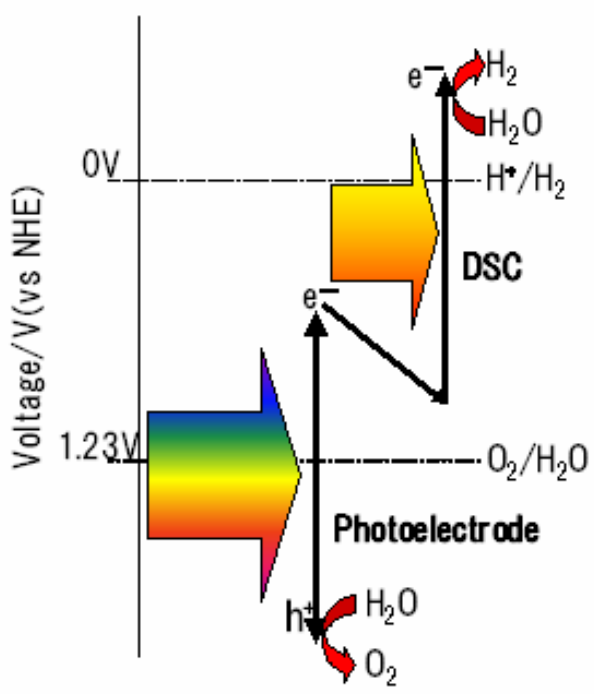

Fig. 6. A conceptual scheme of tandem cell composed of oxide semiconductor film and DSC

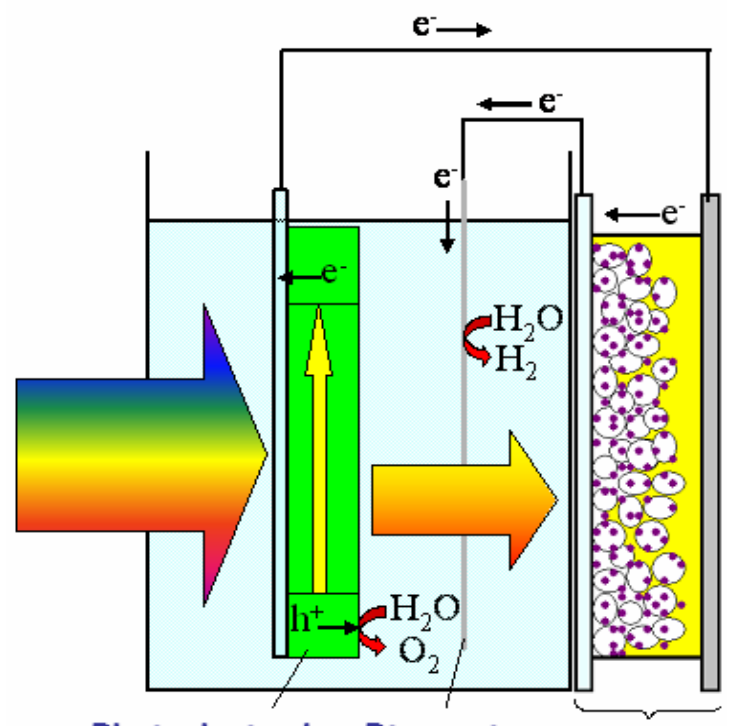

Photoelectrode Pt counter DSC

Fig. 7. Structure of tandem cell system composed of oxide semiconductor photoelectrode and DSC 
that of Red curve. Some increase of resistivity in tandem cell system might occur. Green curve shows I-V curve of the other tandem cell system composed of a mesoporous $\mathrm{TiO}_{2}$ photoelectrode and a two-series connected cell of BDSC. The onset of photocurrent of this system shifted again negatively further to $-1.2 \mathrm{~V}$. However photocurrent was not improved. This means a tandem cell system composed of a two-series-connected BDSC, which has a photovoltage of $1.4 \mathrm{~V}$, is not necessary to use for improvng photocurrent. STH efficiency of this tandem cell system using a single cell was $0.53 \%$, which was 2 times higher than that, $0.32 \%$, of mesoporous $\mathrm{TiO}_{2}$ photoelectrode with $10 \mu$ thickness at the applied potential of $0.35 \mathrm{~V}$ vs RHE.

Figure 9 shows I-V curves of three different systems under simulated solar light irradiation (AM1.5, 100mW/cm² one sun). As the case of $\mathrm{TiO}_{2}$ photoelectrode systems, I-V curves of $\mathrm{WO}_{3}$ photoelectrode systems were also measured using a two-electrode system. Red curve shows I-V curve of mesoporous $\mathrm{WO}_{3}$ photoelectrode, which was already described in section 3.3. Film thickness of this mesoporous $\mathrm{WO}_{3}$ photoelectrode was about $1.5 \mu$. The onset of photocurrent of this system was about $0.7 \mathrm{~V}$ vs counter electrode. To obtain a steady state photocurrent, $2.25 \mathrm{~mA} / \mathrm{cm}^{2}$, at least $1.2 \mathrm{~V}$ of applied potential is requested in this system. Blue curve shows I-V curve of a tandem cell system composed of a mesoporous $\mathrm{WO}_{3}$ photoelectrode and a single cell of BDSC. The onset of photocurrent of this system shifted negatively about $0.7 \mathrm{~V}$, which is almost the same value of the photovoltage (Voc) of a single cell of BDSC, and it was about $0.05 \mathrm{~V}$. About $0.2 \mathrm{~mA} / \mathrm{cm}^{2}$ of photocurrent was obtained without any applied potential in this system. The improvement of photocurrent was not significant. This means a single cell tandem system is not useful for $\mathrm{WO}_{3}$ photoelectrode system. Green curve shows I-V curve of the other tandem cell system composed of a mesoporous $\mathrm{WO}_{3}$ photoelectrode and a twoseries connected cell of BDSC, which has a photovoltage of $1.4 \mathrm{~V}$. The onset of photocurrent of this system shifted about $0.7 \mathrm{~V}$ again negatively down to $-0.7 \mathrm{~V}$. In this case, photocurrent at $0 \mathrm{~V}$ applied potential was $2.1 \mathrm{~mA} / \mathrm{cm}^{2}$. STH efficiency of this tandem cell system using a two-series connected cell of BDSC was $2.58 \%$, which was about 6 times higher than that, $0.44 \%$, of mesoporous $\mathrm{WO}_{3}$ photoelectrode only at the applied potential of $0.9 \mathrm{~V}$ vs RHE. A significant improvement of STH efficiency was observed by a tandem cell system composed of a mesoporous $\mathrm{WO}_{3}$ photoelectrode and a two-series connected cell of BDSC. At applied potential of $1.4 \mathrm{vs}$ counter electrode, $2.25 \mathrm{~mA} / \mathrm{cm}$ of steady state photocurrent was obtained. Therefore, an ideal STH efficiency obtained from this $\mathrm{WO}_{3}$ photoelectrode will become $2.76 \%$.

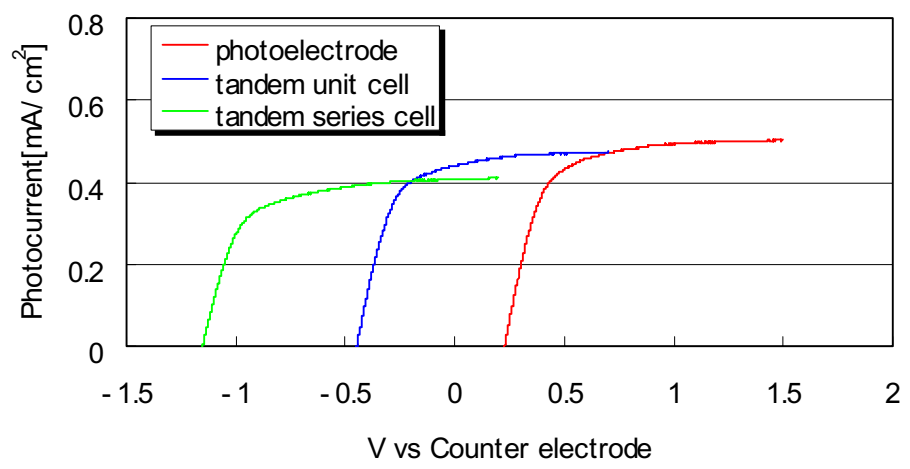

Fig. 8 Three I-V curves of $\mathrm{TiO}_{2}$ photoelectrode systems under simulated solar light irradiation (AM1.5, $100 \mathrm{~mW} / \mathrm{cm}^{2}$, one sun).

Electrolyte solution used: $0.1 \mathrm{~N}-\mathrm{NaOH}$ aqueous solution, Red curve: a mesoporous $\mathrm{TiO}_{2}$ photoelectrode system $\left(\mathrm{TiO}_{2}\right.$ photoelectrode only), Blue curve: a tandem cell system composed of a mesoporous $\mathrm{TiO}_{2}$ photoelectrode and a single BDSC, Green curve: a tandem cell system composed of a mesoporous $\mathrm{TiO}_{2}$ photoelectrode and a two-series-connected BDSC.

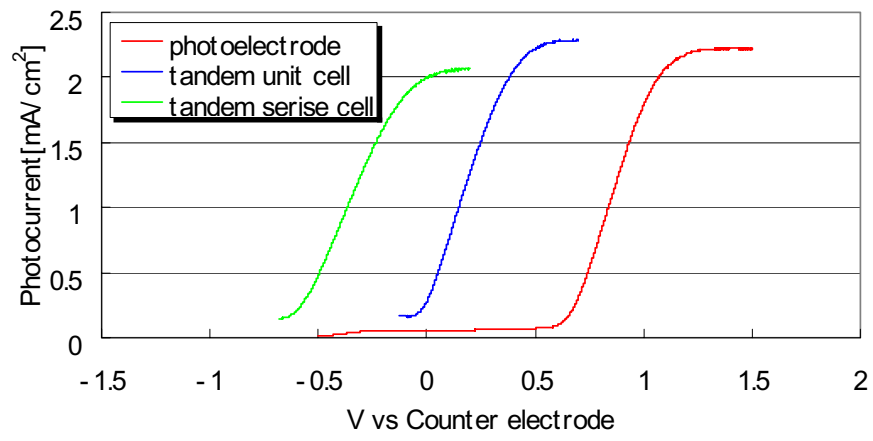

Fig. 9 Three I-V curves of $\mathrm{WO}_{3}$ photoelectrode systems under simulated solar light irradiation (AM1.5, $100 \mathrm{~mW} / \mathrm{cm}^{2}$ one sun).

Electrolyte solution used: $0.1 \mathrm{~N}-\mathrm{H}_{2} \mathrm{SO}_{4}$ aqueous solution, Red curve: a mesoporous $\mathrm{WO}_{3}$ photoelectrode system $\left(\mathrm{WO}_{3}\right.$ photoelectrode only), Blue curve: a tandem cell system composed of a mesoporous $\mathrm{WO}_{3}$ photoelectrode and a single BDSC, Green curve: a tandem cell system composed of a mesoporous $\mathrm{WO}_{3}$ photoelectrode and a two-series-connected BDSC. 
Table 1 summarizes performance of solar hydrogen production over various kinds of oxide semiconductor photoelectrodes conducted by our group and data obtained from current publications. As to $\mathrm{WO}_{3}$ photoelectrode, our result is not the best datum among them. Photocurrent at $1.5 \mathrm{~V}$ applied potential changes from $2.2 \mathrm{~mA} / \mathrm{cm}^{2}$ to $3.6 \mathrm{~mA} / \mathrm{cm}^{2}$. It depends on preparation condition of $\mathrm{WO}_{3}$ photoelectrode and measuring condition such as electrolyte species $\left(\mathrm{H}_{2} \mathrm{SO}_{4}\right.$, $\mathrm{HClO}_{4}, \mathrm{H}_{3} \mathrm{PO}_{4}$ ) and its concentration. Miller and co-workers prepared $\mathrm{WO}_{3}$ film by low temperature reactive sputter process. ${ }^{21)}$ On the other hand. Augustynski group and our group prepared $\mathrm{WO}_{3}$ film using wet process. It is speculated that more than $4.0 \mathrm{~mA} / \mathrm{cm}^{2}$ will be obtained by optimization of preparation and reaction conditions. This means about $5 \%$ of STH efficiency might be possible using tandem cell system. It is also possible to fabricate monolithic tandem cells without external wiring to connect oxide semiconductor film photoelectrode and DSC. This has a great advantage to simple production of solar hydrogen. One of examples was prepared by Park and Bard. ${ }^{30)}$ STH efficiency of our $\mathrm{Fe}_{2} \mathrm{O}_{3}$ tandem cell system was about $0.5 \%$. This is almost the same efficiency of our $\mathrm{TiO}_{2}$ photoelectrode at this moment. However, Graetzel and co-workers reported such a high photocurrent as $2.0-3.0 \mathrm{~mA} / \mathrm{cm}^{2}$ at applied potential of $1.5 \mathrm{~V}$ by changing the morphology of $\mathrm{Fe}_{2} \mathrm{O}_{3}$ and modification of surface by other element ions. ${ }^{14,24)}$ Therefore $\mathrm{Fe}_{2} \mathrm{O}_{3}$ photoelectrode might be also promising. In addition, $\mathrm{Fe}_{2} \mathrm{O}_{3}$ is abundant, low-cost and robust materials. Further efficiency improvement is requested. $\mathrm{BiVO}_{4}$ has absorption edge at $550 \mathrm{~nm}$, which is located at the middle between that of $\mathrm{Fe}_{2} \mathrm{O}_{3}$, $600 \mathrm{~nm}$, and that of $\mathrm{WO}_{3}, 470 \mathrm{~nm}$. Therefore $\mathrm{BiVO}_{4}$ is also attractive material as oxygen evolution photoelectrode. Obtained photocurrent at $1.5 \mathrm{~V}$ was $0.7 \mathrm{~mA} / \mathrm{cm}^{2}$ and STH efficiency of tandem cell system was $0.86 \%$ at this moment. However, further improvement is strongly anticipated by process optimization.

Table 1 Performance of solar hydrogen production over oxide semiconduct or photoelectrodes

\begin{tabular}{|c|c|c|c|c|c|c|}
\hline \multirow[t]{2}{*}{ Photoelectrode } & \multirow[t]{2}{*}{ Electrolyte } & \multirow{2}{*}{$\frac{\text { Onset of I-V curve }}{\text { V vs NHE }}$} & \multicolumn{2}{|c|}{ Photocurrent at $1 \mathrm{~V}$ Photocurrent at $1.5 \mathrm{~V}$} & \multirow{2}{*}{$\begin{array}{l}\eta_{\text {p.e. }} \\
\% \\
\end{array}$} & \multirow{2}{*}{$\eta_{\text {tandem }}$} \\
\hline & & & $\mathrm{mA} / \mathrm{cm}^{2}$ & $\mathrm{~mA} / \mathrm{cm}^{2}$ & & \\
\hline $\mathrm{TiO}_{2}$ (Anatase) & $0.1 \mathrm{M}-\mathrm{NaOH}$ & 0.16 & 0.44 & 0.44 & 0.31 at $0.35 \mathrm{~V}$ & 0.54 \\
\hline $\mathrm{TiO}_{2}$ (Anatase) & 1.0M-NaOH & 0.17 & 0.58 & 0.58 & 0.44 at $0.35 \mathrm{~V}$ & 0.71 \\
\hline S-doped $\mathrm{TiO}_{2}$ & $0.1 \mathrm{M}-\mathrm{NaOH}$ & 0.19 & 0.20 & 0.30 & 0.12 at $0.55 \mathrm{~V}$ & 0.37 \\
\hline $\mathrm{WO}_{3}$ & $0.1 \mathrm{M}-\mathrm{H}_{2} \mathrm{SO}_{4}$ & 0.70 & 1.80 & 2.25 & 0.44 at $0.90 \mathrm{~V}$ & 2.77 \\
\hline $\mathrm{BiVO}_{4}$ & $0.1 \mathrm{M}-\mathrm{NaOH}$ & 0.40 & 0.30 & 0.70 & 0.08 at $0.95 \mathrm{~V}$ & 0.86 \\
\hline $\mathrm{Fe}_{2} \mathrm{O}_{3}$ & $0.1 \mathrm{M}-\mathrm{NaOH}$ & 0.95 & 0.01 & 0.40 & 0.003 at $1.0 \mathrm{~V}$ & 0.49 \\
\hline $\mathrm{WO}_{3}$ & $1.0 \mathrm{M}-\mathrm{HClO}_{4}$ & & & $2.4-2.5$ & J. Augustynski & ki et al..13) \\
\hline WO3 & $3.0 \mathrm{M}-\mathrm{H}_{2} \mathrm{SO}_{4}$ & & & $3.5-3.6$ & J. Augustynsk & ki et al. ${ }^{19)}$ \\
\hline $\mathrm{WO}_{3}$ & $0.33 \mathrm{M}-\mathrm{H}_{3} \mathrm{PO}_{4}$ & & & $3.4^{*}$ & E. L. Miller et & al. ${ }^{21)}$ \\
\hline $\mathrm{Fe}_{2} \mathrm{O}_{3}$ & $1.0 \mathrm{M}-\mathrm{NaOH}$ & & & $2.5^{* *}$ & M. Graetzel et & al. 24$)$ \\
\hline $\mathrm{Fe}_{2} \mathrm{O}_{3}$ & $1.0 \mathrm{M}-\mathrm{NaOH}$ & & & 1.9 & M. Graetzel et & al. ${ }^{14)}$ \\
\hline \multicolumn{7}{|c|}{$\begin{array}{l}\eta_{\text {p.e: }}: \text { STH efficiency of oxide semiconductor photoelectrode at the a } \\
\eta_{\text {tandem: }}: \text { STH efficiency of tandem cell system composed of a oxide } \\
\text { DSC (Voc }=1.5 \mathrm{~V}) \\
\text { Irradiation source: Solar simulator (AM1.5, } 100 \mathrm{mw} / \mathrm{cm}^{2} \text {, one sun) } \\
\text { Size of photoelectrode: } 1 \mathrm{~cm}-\text { by- } 1 \mathrm{~cm}\end{array}$} \\
\hline \multicolumn{7}{|c|}{$\begin{array}{l}\text { *: Sputtered film } \\
* *: 130 \mathrm{mw} / \mathrm{cm}^{2} \quad(1.3 \mathrm{sun})\end{array}$} \\
\hline
\end{tabular}




\section{CONCLUSION}

Solar hydrogen production using tandem cell system composed of an oxide semiconductor photoelectrode and a two-series-connected dye-sensitized solar cell is very promising. At present, STH efficiency is around 3-4\%. However, much improvement of STH efficiency is anticipated by optimization of photoelectrode preparation and water splitting reaction conditions. New oxide semiconductor materials as photoelectrodes are also expected to be developed. It is speculated that more than 5\% STH efficiency will be obtained by tandem cell system in near future. This suggests a costeffective and practical solar hydrogen production process might be brought by this tandem cell system.

\section{ACKNOWLEDGEMENT}

Authors would like to thank The Nissan Science Foundation for their financial support to this research.

\section{REFERENCES}

1. J. Augustynsiki, G. Calzaferri, J. C. Courvoisier, M. Graetzel, Hydrogen Energy Progress XI, Proceedings of the World Hydrogen Energy Conference, 3, 2379-2387(1996).

2. A. Fujishima, K. Honda, Nature, 238,37-38(1972).

3. "Photocatalysis" edited by M. Kaneko and I. Okura, Kodansha-Springer,(2002).

4. A. Kudo and H. Kato, Chem. Phys. Lett., 331, 337(2000).

5. K. Sayama and H. Arakawa, J. Chem. Soc., Farady Trans., 93, 1647-1654(1996).

6. H. Arakawa and K. Sayama, Catalysis Surveys from Japan, 4, 75-80(2000).

7. R. Asahi, T. Morikawa, T. Ohwaki, K.Aoki, Y. Taga, Science, 293, 269(2001).

8. Z. Zou, J. Ye, H. Arakawa, Chem. Phys. Lett., 343, 303(2001).

9. Z. Zou, J. Ye, H. Arakawa, Catal. Lett., 75, 209(2001).

10. Z. Zou, J. Ye, K. Sayama, H. Arakawa, Nature, 414, 625-627(2001).

11. K. Maeda, T. Takata, M. Hara, N. Saito, Y. Inoue, H. Kobayashi, K. Domen, J. Am. Chem. Soc., 127, 8286(2005).

12. K. Sayama, K. Mukasa, R. Abe, Y. Abe, H.Arakawa, Chem. Commun., 2001, 2416.

13. C. Santato, M. Ulman, J. Augustynski, J. Phys. Chem., 105, 936(2001).

14. I. Caser, A. Kay, J. A. Gonzalez, M. Graetzel, J. Am. Chem. Soc., 128, 4582-4583(2006).

15. H. Arakawa, C. Shiraishi, A. Takeuchi, T. Yamaguci, Proc. of SPIE, 6340, 63400G(2006).

16. S. U. M. Khan, M. Al-Shahny, W. B. Jr. Ingler, Science, 297, 2243-2245(2002).

17. T. Ohno, M. Akiyoshi, T. Umebayashi, K.Asai, T. Mitsui, M. Matsumura, Applied. Catal. A: General, 265, 115121(2004).

18. C. Santato, M. Odziemkowski, M. Ulman, J. Augustynski, J. Am. Chem. Soc., 123, 10639(2001).

19. R. Solarska, C. Santato, C. Jorand-Sartoretti, M. Ulmann, J. Augustynski, J. Appl. Electrochem., 35, 715(2005).

20. J. Augustinski, R. Solarska, H. Hagemam, C. Santato, Proc. of SPIE, 6340, 63400J(2006).

21. E. L. Miller, B. Marsen, B. Cole, M. Lum, Electrochemical and Solid-State Letters, 9, G248(2006).

22. A. Kudo, K. Omori, H. Kato, J. Am. Chem. Soc., 121, 11459(1999).

23. K. Sayama, A. Nomura, T. Arai, T. Sugita, R. Abe, M.Yanagida, T. Oi, Y. Iwasaki, Y. Abe, H. Sugihara, J. Phys. Chem., 110, 11352(2006).

24. A. Duret, M. Graeztzel, J. Phys. Chem., 109, 17184(2005).

25. M. Graetzel, Nature, 414,338-334(2001).

26. Z.-S. Wang, H. Kawauchi, T. Kashima, H. Arakawa, Coordination Chemistry Review, 248, 1381(2004).

27. Z.-S. Wang, T. Yamaguchi, H. Sugihara, H. Arakawa, Langmuir, 21, 4272(2005).

28. H. Arakawa, T. Yamaguchi, A. Takeuchi, S. Agatsuma,, 2006 IEEE $4^{\text {th }}$ World Conference on Photovioltaic Energy Conversion, 1, 36(2006).

29. Hydrogen Solar Ltd., http://www.hydrogensolar.com

30. J. H. Park, A. J. Bard, Electrochemical and Solid-State Letters, 9, E5(2006).

xxxviii 